\title{
Innate Immune Signaling and Role of Glial Cells in Herpes Simplex Virus- and Rabies Virus-Induced Encephalitis
}

\author{
Lena Feige $^{1}\left(\mathbb{D}\right.$, Luca M. Zaeck ${ }^{2}(\mathbb{D})$, Julia Sehl-Ewert ${ }^{3}\left(\mathbb{D}\right.$, Stefan Finke ${ }^{2} \mathbb{D}$ and Hervé Bourhy ${ }^{1, *(\mathbb{D})}$ \\ 1 Institut Pasteur, Université de Paris, Lyssavirus Epidemiology and Neuropathology, 28 Rue Du Docteur Roux, \\ 75015 Paris, France; lena.feige@pasteur.fr \\ 2 Institute of Molecular Virology and Cell Biology, Friedrich-Loeffler-Institut (FLI), \\ Federal Institute of Animal Health, Südufer 10, 17493 Greifswald-Insel Riems, Germany; \\ Luca.Zaeck@fli.de (L.M.Z.); Stefan.Finke@fli.de (S.F.) \\ 3 Department of Experimental Animal Facilities and Biorisk Management, Friedrich-Loeffler-Institut (FLI), \\ Federal Institute of Animal Health, Südufer 10, 17493 Greifswald-Insel Riems, Germany; \\ julia.sehl-ewert@fli.de \\ * Correspondence: herve.bourhy@pasteur.fr
}

check for updates

Citation: Feige, L.; Zaeck, L.M.; Sehl-Ewert, J.; Finke, S.; Bourhy, H. Innate Immune Signaling and Role of Glial Cells in Herpes Simplex Virusand Rabies Virus-Induced Encephalitis. Viruses 2021, 13, 2364. https://doi.org/10.3390/v13122364

Academic Editor: Akinori Takaoka

Received: 24 October 2021

Accepted: 18 November 2021

Published: 25 November 2021

Publisher's Note: MDPI stays neutral with regard to jurisdictional claims in published maps and institutional affiliations.

Copyright: (c) 2021 by the authors. Licensee MDPI, Basel, Switzerland. This article is an open access article distributed under the terms and conditions of the Creative Commons Attribution (CC BY) license (https:/ / creativecommons.org/licenses/by/ $4.0 /)$.

\begin{abstract}
The environment of the central nervous system (CNS) represents a double-edged sword in the context of viral infections. On the one hand, the infectious route for viral pathogens is restricted via neuroprotective barriers; on the other hand, viruses benefit from the immunologically quiescent neural environment after CNS entry. Both the herpes simplex virus (HSV) and the rabies virus (RABV) bypass the neuroprotective blood-brain barrier (BBB) and successfully enter the CNS parenchyma via nerve endings. Despite the differences in the molecular nature of both viruses, each virus uses retrograde transport along peripheral nerves to reach the human CNS. Once inside the CNS parenchyma, HSV infection results in severe acute inflammation, necrosis, and hemorrhaging, while RABV preserves the intact neuronal network by inhibiting apoptosis and limiting inflammation. During RABV neuroinvasion, surveilling glial cells fail to generate a sufficient type I interferon (IFN) response, enabling RABV to replicate undetected, ultimately leading to its fatal outcome. To date, we do not fully understand the molecular mechanisms underlying the activation or suppression of the host inflammatory responses of surveilling glial cells, which present important pathways shaping viral pathogenesis and clinical outcome in viral encephalitis. Here, we compare the innate immune responses of glial cells in RABV- and HSV-infected CNS, highlighting different viral strategies of neuroprotection or Neuroinflamm. in the context of viral encephalitis.
\end{abstract}

Keywords: astrocytes; microglia; viral encephalomyelitis; herpes simplex virus; rabies virus

\section{Viral Infection Routes to Enter the Central Nervous System \\ 1.1. General Considerations}

In contrast to other tissues, the micromilieu of the central nervous system (CNS) tightly controls brain immunity by different and unique immunomodulatory properties: the presence of tightly controlled physical barriers, the lack of a classical lymphatic drainage system, the presence of functional lymphatic vessels [1], the relative deficiency of constitutive MHC expression, and the immunomodulatory properties regulated via the expression of immunosuppressive proteins [2]. In the context of infection, access of pathogens to the CNS is limited by the blood-brain barrier (BBB), comprising a tightly connected endothelium and the glia limitans lining the CNS parenchyma [3]. If a pathogen gains access to the CNS, resident and innate immune cells mount innate immune responses, which lead to the recruitment of adaptive immune cells from the periphery. Under physiological conditions, immune responses in the CNS are limited to protect vulnerable and nonrenewable cells, such as neurons. Blood-borne viral pathogens, however, have evolved three different mechanisms to cross the neuroprotective BBB (1): (i) transcellular entry (West Nile virus, 
Zika virus, Japanese encephalitis virus), (ii) paracellular entry (Marburg virus, dengue virus, Ebola virus), and (iii) the so-called 'Trojan horse entry' in which the virus enters the CNS via circulating immune cells (HIV, Japanese encephalitis virus, measles virus, canine distemper virus) [4]. In contrast to paracellular transport, transcellular transport usually does not depend on the disruption of junction proteins, the actin cytoskeleton, or the basal lamina [4]. It is further subdivided into (i) free and passive diffusion limited to lipophilic substances, (ii) carrier-mediated transport, and (iii) vesicle-mediated transport [5]. In contrast, direct entry mechanisms (RABV, HSV, poliovirus, henipavirus) aim to bypass the neuroprotective barriers and enter the CNS via infection of nerve endings and long-distance transport of viral particles within the neuronal network (Figure 1) [2]. The exact mechanism of how viral pathogens such as RABV and HSV, both causing lethal encephalitis in humans, efficiently infect the CNS and how host immune responses contribute to or counteract efficient neuroinvasion remains a question of significant interest.

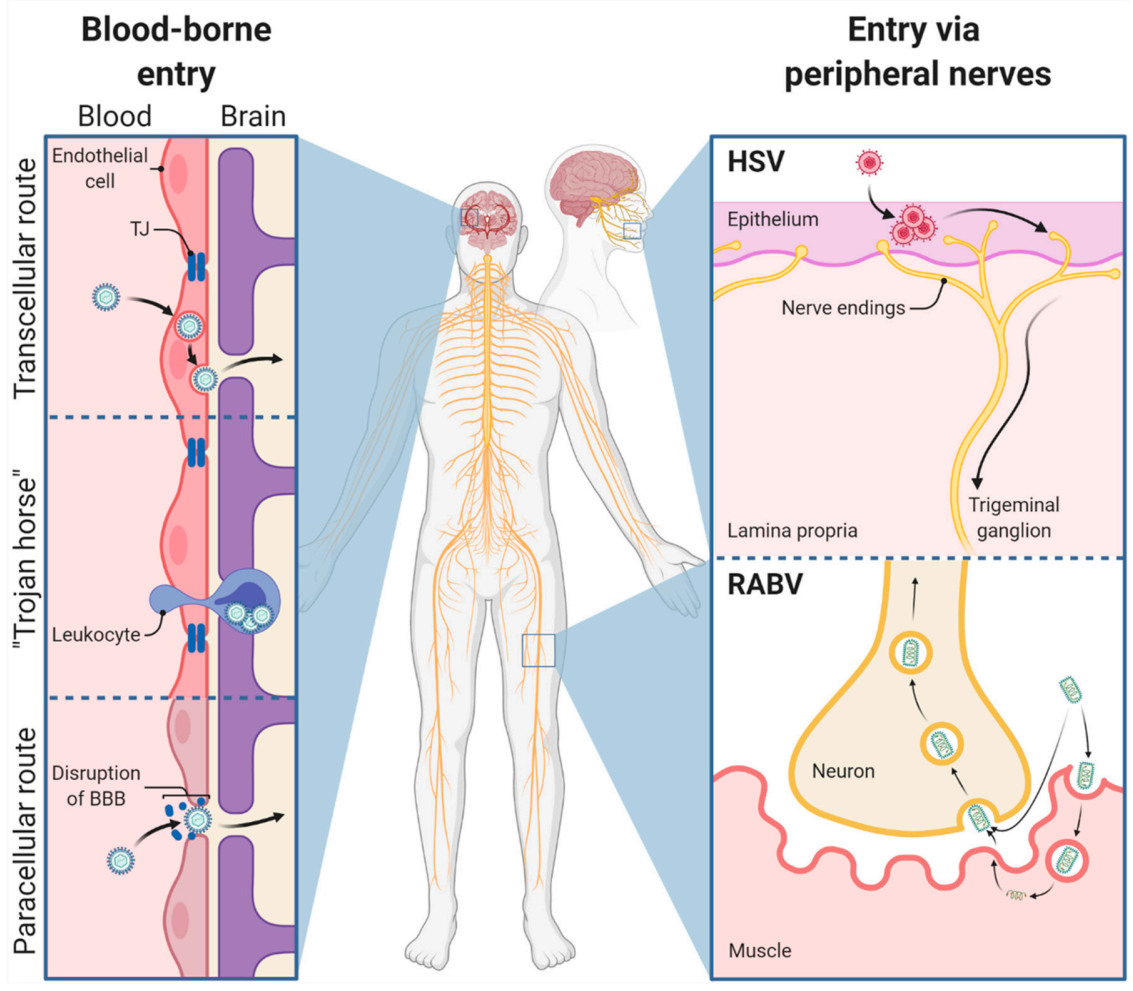

Figure 1. Infection routes of neurotropic viruses. Pathogens can enter the CNS via two distinct routes, the blood (left) or the nervous system (right). Entry via the bloodstream is mediated by crossing the BBB (left) or the blood-cerebrospinal fluid barrier (not illustrated here). The mechanisms for crossing the BBB include the transcellular, 'Trojan horse', or paracellular routes [2]. Transcellular transport describes the transport of viruses by a direct diffusion pathway across the endothelial monolayer [5]. The 'Trojan horse' route refers to viruses that infect peripheral cells and enter the CNS parenchyma via paracellular or transcellular means. Paracellular entry of viruses is associated with the disruption of the BBB preferably via alterations in the phosphorylation status of tight junction proteins, the disruption of the actin cytoskeleton, or the disruption of the basal lamina [4]. In contrast to this, RABV and HSV bypass the neuroprotective barriers and enter the CNS via retrograde transport along peripheral nerves (right). Upon the bite of an infected rabid animal, RABV enters the broken skin and infects peripheral nerves at the motor endplate of neuromuscular junctions or other innervated tissues. After receptor-mediated entry, RABV is retrogradely transported in endosomal transport vesicles to higher-order neurons until the virus reaches the CNS [6]. HSV enters the termini of sensory neurons, which innervate the exposed skin. It is then retrogradely transported to autonomic nerve terminals of neurons in the trigeminal ganglion (TG), in which viral DNA remains in a latency phase. After reactivation, HSV can reach the brain via anterograde transport [7]. 
Rabies, one of the oldest and most fatal diseases described in humans [8], is still responsible for approximately 60,000 human deaths per year [9]. About 50\% of fatal cases occur in children, causing about 3.7 million disability-adjusted life years [10]. The causative agent of rabies is the rabies virus (RABV), a bullet-shaped negative-sense singlestranded RNA rhabdovirus belonging to the order Mononegavirales. RABV is mostly (>99\%) transmitted to humans upon the bite of a rabid dog [6]. Thereafter, canine RABV variants replicate locally in striated muscle cells and spread to the peripheral nervous system (PNS) via the neuromuscular junction [11,12]. Compared with coyote street RABV (COSR), the silver-haired bat variant of RABV (SHBRV) has shown a more effective local replication in epithelial cells and fibroblasts, two cellular components of the dermis [13]. Thus, differences in RABV strains seem to define RABV tropism and replication potential at the entry site. Once inside the PNS, RABV is transported by motor neurons in the retrograde direction [14]. Dependent on the site of infection, it may also use sensory and autonomic neurons to reach the CNS [15]. Inoculation of the planar footpad of adult mice with RABV leads to the capture of viral particles by dorsal root ganglia and their transport to the spinal cord and later the brain [16]. Unlike necrotizing HSV encephalitis (HSE), RABV preserves an intact neuronal network until the final stage of the disease by inhibiting apoptosis and limiting inflammation within the CNS, two crucial factors ensuring RABV transmission [17].

Around a week after the onset of symptoms, major histopathological lesions are still absent in the RABV-infected CNS. Clinical onset of the disease develops after RABV is widely disseminated in the CNS. Neurons, which have been infected with RABV for several days, do not exhibit cytopathic changes and remain metabolically viable in vivo [18-22]. In mice, the development of severe clinical disease occurs along with protein expression changes in ion homeostasis as well as docking and fusion of synaptic vesicles to the presynaptic membranes [23], which is hypothesized to be responsible for the defective neurotransmission recognized in rabies [24]. In humans, rabies manifests in two clinical forms: furious rabies and paralytic rabies [25]. In both forms, RABV-induced dysfunction of the local dorsal root ganglia causes pain, paresthesia, or pruritus. After the prodrome, encephalitic patients show hypersalivation and periods of agitation alternating with lucidity, hydrophobia, and difficulty swallowing, ultimately leading to death. The paralytic form leads to an early onset of muscle weakness, followed by a longer time between disease onset and death or coma, compared with the encephalitic form. Following the onset of symptoms, rabies is almost invariably fatal [26]. In contrast to humans, several RABV-exposed mammal species produce RABV-neutralizing antibodies that clear RABV prior to CNS invasion [27-29]. As a result, subclinical or mitigated infections show mild or no symptoms. These nonlethal RABV infections have been shown or suggested for bats [27,28,30,31], cattle [29], wild canids [32-34], and nonhuman primates [34-36]. Although pre- and postexposure vaccinations against rabies are available [37,38], no treatment exists thus far, which shows a high therapeutic efficiency. In 2004, a young and unvaccinated patient from Wisconsin survived rabies [39]. The therapeutic approach used, more specifically the induction of a therapeutic coma and the use of N-methyl D-aspartate receptor antagonist therapy, is since then known as the Milwaukee protocol [39]. Despite its relentless promotion, there are at least 31 documented failures using the Milwaukee protocol, raising concerns about its efficiency [40]. Therefore, improving our understanding of the interplay between RABV and the host immune system may result in improved medical management of rabid patients.

Like RABV, the herpes simplex virus (HSV) invades the CNS by bypassing the BBB via retrograde transport along nerves. HSV-1 is a double-stranded DNA virus belonging to the highly neurotropic alphaherpesviruses. It is assumed that after initial replication in epithelial cells, HSV enters sensory nerve endings and establishes lifelong latency in peripheral sensory ganglia, such as the TG. Unlike RABV, alphaherpesviruses rarely spread to the CNS of immunocompetent hosts. Nevertheless, HSE does not occur more frequently in immunocompromised than in immunocompetent hosts, since it is believed that both virus-mediated and indirect immune-mediated mechanisms contribute to the observed CNS damages [41]. In contrast to immunocompetent patients, immunosuppressed patients 
might more likely show atypical or aggressive infections [42]. In sporadic cases, spread to the CNS can result from primary herpetic infection, reinfection by a second herpesvirus, or reactivation of latent HSV [43]. After CNS invasion, HSV-1 causes necrotizing meningoencephalitis [44]. In this regard, HSV-1 clearly differs from RABV since HSV-1 infection leads to a fulminant inflammatory response while this does not occur upon RABV infection. HSE, which is the most common form of sporadically occurring fatal encephalitis in humans worldwide, is mainly caused by HSV-1, with HSV-2 representing less than $10 \%$ of the cases, which are mostly affecting neonates. The neonatal form of HSE involves the periventricular white matter, mainly spares temporal and frontal lobes [45], and is rarely hemorrhagic [45,46]. In contrast, reactivation of HSV in the trigeminal sensory ganglion of older children and adolescents can lead to virus dissemination in temporal and frontal lobes [47].

To date, the mechanisms leading to CNS access and strong temporofrontal lobe tropism of HSV-1 are not fully understood. Unlike rabies, HSE caused by HSV-1 shows a bimodal age distribution and occurs in either children or adolescents younger than 20 years, or in adults over 50 years [48]. Although the pathogenesis of neonatal HSE is not well understood, it has been hypothesized that different routes of virus entry to the brain may account for different localizations of virus dissemination observed in HSE. In infants, HSV may spread hematogenously across the immature BBB [45]. In adults, however, HSV-1 most likely enters the CNS via the trigeminal or olfactory route. After nonspecific clinical signs, HSE patients develop neurological deficits as well as characteristic behavioral and personality changes, such as disorientation, speech disturbances, and focal or diffuse neurological signs, such as seizures or hemiparesis [49,50]. A prospective clinical study in 2007 showed that the high mortality rate of $70 \%$ of HSE can be reduced to $5 \%$ using acyclovir therapy [51]. However, survivors suffer from severe neuropsychological longterm sequelae, including mainly cognitive dysfunctions [52].

\subsection{Which Factors Support RABV and HSV Replication in the Nervous System?}

RABV enters the cell via the interaction of the RABV glycoprotein (G-protein) with RABV entry receptors, triggering clathrin-mediated endocytosis of RABV particles [53-55]. One reason for a preferential infection of neuronal tissues might be the higher expression levels of RABV entry receptors on neurons and postsynaptic membranes of muscle cells in the neuromuscular junction [56]. Although the presence of RABV receptors might not be sufficient for the productive infection of non-neuronal cells due to inhibition by respective antiviral responses of the target cells, the presence of a specific receptor represents a prerequisite of infection. After viral entry into the cell, the RABV G-protein induces fusion of the viral envelope with the endosomal membranes liberating the viral nucleocapsid into the cytoplasm. In detail, the viral G-protein is a class III membrane fusion protein that undergoes a conformational change in the acidic environment of the endosome [54,57,58]. Like HSV, after entry at presynaptic axon membranes, RABV particles are transported in a retrograde fashion along microtubules [59-61]. Although the viral phosphoprotein (P-protein) has been shown to interact with a light chain of the dynein motor complex [62,63], axonal transport of RABV to the CNS is independent of this interaction [64]. More specifically, the binding domain of the viral P-protein seems to rather have a crucial role in RABV primary transcription compared with that in the intracellular transport of RABV [65]. For longdistance axonal transport, enveloped RABV virions are transported within internalized endosomes $[60,61]$. Upon arrival in the neuronal cell body, the viral polymerase L initiates transcription by using the ribonucleoprotein complex as the template [65]. Once a certain threshold of viral nucleoprotein (N-protein) is synthesized, viral replication is initiated, leading to the production of a full-length positive-sense RNA antigenome [66-68]. This intermediate serves as the template for the full-length negative-sense genome. The G-protein is inserted into the plasma membrane $[69,70]$. The connection of the viral ribonucleoprotein with the G-protein comprising membranes triggers membrane envelopment. Subsequently, the matrix protein (M-protein) mediates RABV budding [71] for transmission to next-order 
neurons. It is thought that RABV buds from the synapse to start another round of infection in next-order neurons [14]. Consequently, RABV uses trans-synaptic spread to reach the CNS. The brain area in which the infection starts depends on the innervation site of the infected motor neurons. From the brain, RABV centrifugally spreads to salivary glands and several extraneural organs [6,72,73]. In contrast to HSV [44], RABV does not persist in the nervous system and ultimately leads to the death of the host [26].

Unlike spreading via the neuromuscular junction, HSV-1 must overcome the barrier between epithelial cells and free-ending nerve fibers from the PNS. After initial replication, neuroinvasion of HSV-1 is mediated via the herpesviral conserved deubiquitinase domain of the tegument protein pUL36 [74,75]. Sensory neurons are readily infected, but if deeper layers of the epithelium are affected, also efferent and autonomic nerve fibers can be infected. Following fusion-mediated entry in neurons at axonal nerve endings, virus capsids and their inner tegument layer are released into the cell $[76,77]$, which is in contrast to the clathrin-mediated and receptor-dependent endocytosis of RABV $[55,78]$. Comparable to intraendosomal RABV particles, HSV-1 nucleocapsids are then retrogradely transported along microtubules, which are mainly mediated by the viral proteins pUL36 and pUL37 [77,79] together with the cellular dynein motor complex [80]. Once in the cell body, virions dock at nuclear pores and deliver viral DNA into the neuronal nucleus [81]. Following primary infection, latency is established in infected neurons, where progression of productive infection and subsequent cell death are blocked [82]. During latency, the production of viral proteins is abrogated due to the inactivity of the viral transcriptional activator UL48; instead, the latency-associated transcript (LAT), a nonprotein coding RNA, is synthesized. LAT inhibits apoptosis of the infected cell and mediates the maintenance of the latent state [83]. After reactivation in sensory ganglia, newly formed viral particles are anterogradely transported back to the periphery, where initial infection originally started. Alternatively, the virus spreads to higher-order neurons via anterograde microtubule-based transport using cellular kinesin motor proteins. Transport back to the periphery leads to the development of HSV lesions (herpes labialis or cold sores), whereas invasion of second-order neurons and transport to the CNS is associated with severe disease [7].

\section{The Role of Glial Cells in Maintaining CNS Homeostasis}

Inside the CNS, the neuronal network is protected from pathogens via resident glial cells, which can be divided into oligodendrocytes, astrocytes, and microglia. Oligodendrocytes are myelin-producing cells of the brain, which insulate neuronal axons and thereby facilitate rapid propagation of axon potentials $[84,85]$. Schwann cells (SCs) represent the counterparts of oligodendrocytes in the PNS and are responsible for forming myelin sheaths around peripheral neurons. In comparison, satellite cells, which are closely related to SCs, ensheath the cell bodies of sensory neurons located in trigeminal and dorsal root ganglia and share similarities with astrocytes [86,87]. Astrocytes are the most abundant cell type in the CNS and play an essential role in the initiation of viral defense in a type I interferon (IFN)-dependent mechanism. They monitor brain development and function, especially by controlling potassium levels, removing toxic substances, and modulating synaptic activity [88]. In contrast, microglia represent a rather small and unique myeloid cell population, which derive from primitive myeloid progenitors from the yolk sac [89]. Due to their similarity to macrophages, microglia are often referred to as the CNS-resident macrophages, which largely contribute to immunosurveillance in the brain $[90,91]$. Under physiological conditions, the homeostatic brain microenvironment constitutively expresses 'off' signals, which prevent astrocytic and microglial activation. Those microglia-astrocyte-neuron interactions are critical for CNS innate immunity [92]. In detail, neurons constitutively express surface molecules or secrete molecules, which inhibit microglial activity. For example, healthy neurons express CD200 to keep CD200R ${ }^{+}$microglia in a quiescent state [93-96]. Additionally, glial-mediated production of IL-10 and related cytokines (IL-19, IL-24) limit glial inflammatory responses and promote immunosuppression in the CNS [97]. 
In the case of neuronal death or injury, the expression of those inhibitory molecules is modulated, leading to the abrogation of microglial and astrocytic suppression [93-96]. Damaged or stressed neurons activate astrocytes and microglia via the release of cytokines (IFN- $\gamma$, IL-6) and chemokines (CX3CL1, CCL2). In response, glial cells sense neuronal damage via cell-specific receptors and produce an array of cytokines (IL-1, IL-6, IL-12, TNF, CCL2, CCL4, CCL5, CCL7, CXCL10) depending on the specific pathogen [98]. This results in the upregulation of MHC I and II proteins on the microglial cell surface $[99,100]$ and the increased expression of adhesion molecules on endothelial cells (ECs) [101,102]. Further, reactive astrocytes also present antigens via MHC I and II proteins during viral encephalitis and neuroinflammatory reactions [103-105]. Apart from neurons, numerous other players, such as peripheral immune cells and peripherally produced molecules, can induce glial activation and subsequent antigen presentation [106].

Infecting mice with a wild-type (wt) bat RABV has revealed the upregulation of microglial-specific CD200R in the virus-infected CNS, suggesting that RABV influences neuron-microglia signaling [107]. In HSE, microglia have been shown to sense HSV-1 through the cyclic guanosine monophosphate-adenosine monophosphate (cGAMP) synthase/stimulator of the interferon gene (cGAS/STING) pathway, initiating the production of type I IFN and immune priming of neighboring cells [108]. Apart from microglia, astrocytes are the main producers of IFN- $\beta$ in the RABV-infected brain [109]. Similarly, astrocytic secretion of IFN- $\beta$ has been shown in other viral CNS infections (e.g., with vesicular stomatitis virus (VSV) and La Crosse virus), suggesting that astrocytes are important immune modulators triggering viral clearance in the infected CNS [110,111].

Since morphological changes in the CNS of rabies patients [112] and infected animals appear mild despite the fatal outcome $[113,114]$, it is believed that neuronal dysfunction is responsible for RABV-induced death [24]. The ability of RABV to antagonize an early IFN response enables the virus to limit apoptosis and inflammation in the CNS [115-117]. Consequently, the innate immune system fails to prime an adaptive immune response in time to clear the virus from the infected CNS. Unlike rabies, HSV infection initiates a fulminant inflammatory cascade, recruiting innate immune cells and activating adaptive immune mechanisms to the infected CNS area (Figure 2).

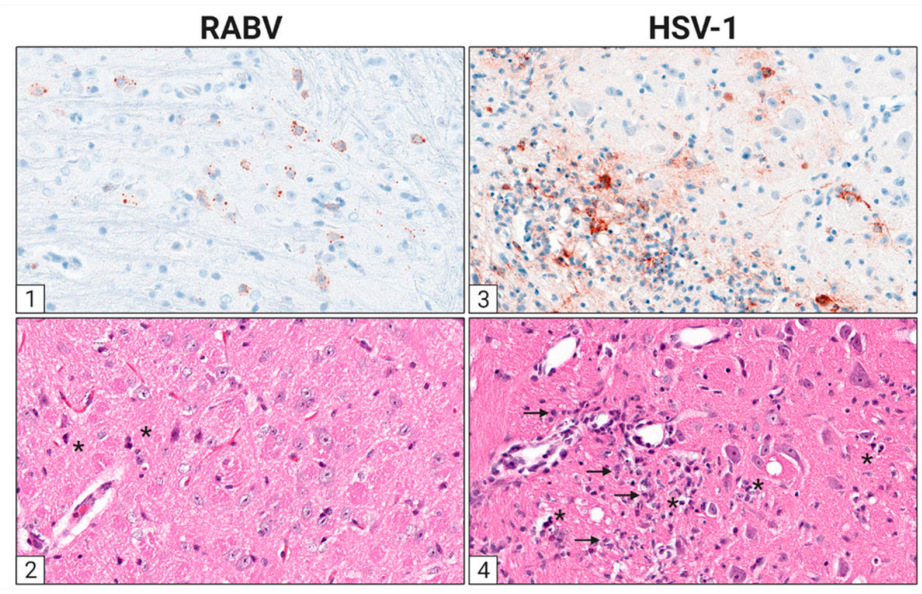

Figure 2. Comparative histopathology of RABV and HSV-1 infection in the murine brain. (1) Multiple brain stem neurons show positive signals against RABV antigen. The microscopic picture presents an immunohistochemistry staining using the ABC method. (2) Only a small number of necrotic neurons (asterisk) are present in the consecutive section of the RABV-infected brainstem. Inflammatory cells are absent. The microscopic picture presents hematoxylin and eosin staining. (3) Multiple neurons and glial cells of a murine brainstem are positive for HSV-1 antigen. The microscopic picture presents immunohistochemistry staining using the ABC method. (4) In contrast to RABV, as demonstrated in the consecutive section, HSV-1 infection induces a marked inflammatory response mainly consisting of infiltrating histiocytes and lymphocytes (arrow). Infected cells are necrotic (asterisk). The microscopic picture presents hematoxylin and eosin staining. 
Although we are far from understanding the exact molecular pathways underlying neuron-glia interactions in the virus-infected CNS, RABV and HSV both modulate the gene expression of signaling molecules, which are important for neuron-glia communication, thereby interfering with CNS homeostasis. Taken together, the outcome of viral infection depends on two main factors: the pathogenicity of the virus and the triggered antiviral response. The latter is mainly mediated by glial cells in the CNS. Both viral pathogenicity and host immune response modulate one another, and their synergistic effects can result in adverse outcomes, due to either a highly pathogenic virus or an inadequate immune response. At the end stage of the disease, RABV leads to an invariably fatal encephalomyelitis by evading the immune response of glial cells, subsequently enabling RABV to extensively replicate in the CNS. In contrast, HSV mediates death by inducing necrotizing inflammation in the CNS, a process that is aggravated by an excessive immune response.

\section{The Cellular Infection Pattern of RABV and HSV in the Nervous System}

As elaborated earlier, RABV and HSV are classically referred to as neurotropic viruses since both preferentially spread to the nervous system [14,118]. Whereas most of the research has succeeded in linking immunoevasive mechanisms of RABV to distinct viral proteins $[119,120]$, it is less understood how they influence the strong neuron-specific tropism of RABV or why in some cases glial cell infection can be detected [121-125]. Deciphering the requirements for a strict neuron-specific tropism or broader host cell multitropism in the nervous system and discovering cell-specific responses restricting viral replication is of utmost importance to understand viral pathogenesis and antiviral host mechanisms.

\subsection{Viral Entry}

Regarding viral tropism, a broad range of cell types, including neuroglia, can be infected in vitro by both field and laboratory-attenuated RABV [122,126-128], contrasting the pronounced neuron-specific tropism in vivo. It is suggested that the neuron-specific tropism of RABV presents a viral adaptation mechanism to avoid immune detection by the host [129]. Different RABV receptors bind to the viral G-protein, of which the neuronal cell adhesion molecule (NCAM) [130], low-affinity nerve growth factor receptor (p75NTR) [131], or metabotropic glutamate receptor subtype 2 (mGluR2) [132] presents bona fide neuronal surface receptor molecules, whereas the nicotinic acetylcholine receptor (nAChR) [133] is expressed in muscle cells and may support RABV amplification prior to neuron infection through motoneuronal endplates. However, RABV receptor expression in mice and humans $[134,135]$ does not positively correlate with cellular susceptibility to $\mathrm{RABV}$ infection, implying that receptor usage alone is not determining the strong neuronspecific tropism of RABV. Recent single-cell sequencing data of human brains revealed that the expression of p75NTR, mGluR2, and nAChR is relatively low in the human brain, whereas NCAM is highly expressed. More specifically, NCAM has been predominantly found on neuronal cells but shown to be also highly expressed on oligodendrocytes and certain astrocyte subsets. In contrast, microglia have shown low or no expression of NCAM in the human brain [136].

A major factor determining tissue- and cell-specific permissivity to HSV infection is the cellular receptor mediating entry of the virus. For HSV-1 cellular entry, different glycoproteins (glycoprotein $(\mathrm{g}) \mathrm{D}, \mathrm{gB}, \mathrm{gH}$, and $\mathrm{gL}$ ) are required to bind to specific cellular receptors. Initially, $\mathrm{gB}$ and $\mathrm{gH}$ attach to cell-surface heparan sulfate proteoglycans, which are present in various cells, including neurons. Next, gD binds to the cell surface receptors nectin-1 (also referred to as poliovirus receptor-like protein 1) or TNF receptor superfamily member 14 (TNFRSF14), also known as herpesvirus entry mediator (HVEM), which mediates the activation of the $\mathrm{gH} / \mathrm{gL}$ complex and subsequently the transformation of $\mathrm{gB}$ into a fusogenic state [137]. For successful fusion of the viral envelope with the cell membrane, a gB receptor such as paired immunoglobulin-like type 2 receptor $\alpha$ (PILRA), another paired-type receptor with homology to PILRA, myelin-associated glycoprotein, 
and myosin heavy chain 9 (MYH9, also known as NMMHC-IIA) is required [137]. The $\mathrm{gD}$ receptor nectin-1 is a member of the immunoglobulin superfamily and is located at cellular adherens and tight junctions involved in the cell-cell adhesion of epithelial and endothelial cells [138]. Most likely, nectin-1 presents the most important receptor for HSV-1 infection of epithelial and neuronal cells $[137,139]$. Although HVEM is widely expressed in the liver, kidney, and lung, as well as in T and B lymphocytes, leukocytes, epithelial cells, fibroblasts, and neurons on which it controls diverse proinflammatory and inhibitory signaling pathways $[140,141]$, it seems to be largely irrelevant for the course of HSE since the patterns of HSV replication in the brain of wt and HVEM knockout mice have been indistinguishable [139]. The distribution of HSV-1 receptors has been examined in the human [141] and murine brain [142]. Specifically, nectin-1, TNFRSF14, and MYH9 have been highly expressed in the human hippocampus, and it has been shown for nectin-1 in the murine hippocampus to be the underlying cause for the higher susceptibility of this brain area to HSV-1 infection. Abundant nectin-1 levels have also been found in sensory, sympathetic, and parasympathetic nerves [143]. Immunohistochemical studies on nectin-1 expression in neuronal and non-neuronal cells of the human nervous tissue have revealed that neurons of the basal ganglia, cerebral cortex, diencephalon, brainstem, spinal cord, and peripheral dorsal root and trigeminal ganglia are highly positive. Further, ependymal cells, choroid plexus epithelial cells, and vascular endothelium have shown strong nectin-1 expression. Variable but still positive immunoreactivity has been present in oligodendrocytes, astrocytes, pericytes, SCs, and satellite cells, demonstrating potential target cells for HSV-1 [142].

In a nutshell, multiple receptors are known to be responsible for the cellular uptake of RABV and HSV. Like RABV, not all the cells expressing the viral entry receptors get predominantly and productively infected by HSV, suggesting that more factors shape HSV tropism.

\subsection{RABV Tropism}

Considering the remarkable tropism of field RABV strains for non-neuronal cells in comparison with less virulent laboratory strains [122] as well as the broad distribution of the potential RABV receptors in the central and peripheral nervous systems $[56,136]$, evidence is accumulating that RABV neuron-specific tropism may not exclusively be a result of a specific receptor expression by neurons. More likely, a lower protective immune response in neurons as compared with other susceptible cell types may result in productive infection. In contrast, entry in non-neuronal cell types seems to result in abortive infection due to immediate and strong innate immune responses $[109,144]$ in a virus-strain-dependent manner [122]. Considering reports about in vivo infection of non-neuronal cells by field RABV [122,123,145-147], the concept of an almost exclusive infection of neurons has to be relativized. In summary, RABV host cell tropism and in vivo spread is due to multiple factors: the presence of RABV cell entry receptors on the plasma membrane, intraneuronal long-distance virus transport processes both at virus entry and after replication, specific trans-synaptic spread between neurons, and the neuronal metabolism, which actively supports RABV replication. Paracrine effects through cytokine release by abortively or productively infected non-neuronal cells such as astrocytes or SCs surrounding neurons $[122,123]$ may also determine the susceptibility and survival of neurons and other cell types that can be easily infected in vitro [127].

\subsubsection{Astrocytes}

Besides receptor usage, negative regulation by cell-type-specific inhibition of virus replication in non-neuronal cells might play a decisive role in viral tropism of neurotropic pathogens. In vivo, abortive infection of astrocytes with RABV SAD carrying the G-protein of the more neurotropic challenge virus standard (CVS) strain has been suggested to be the result of type I IFN induction [109]. In vitro, this correlates with the activation of doublestranded (ds) RNA-dependent mitochondrial antiviral signaling protein (MAVS), whereas 
wt RABV is able to infect astrocytes without exhibiting MAVS activation [144]. Other studies using in vitro neuron or astrocyte cultures have confirmed astrocyte infection by RABV in vitro, without remarking discernible differences between lab-attenuated and field RABV [122,127,148]. A broad quantitative comparison of different recombinant field and lab-attenuated strains in infected mice, however, has highlighted the infection of astrocytes in the CNS after intramuscular infection only with highly virulent field RABV. In addition, no astrocyte infection has been detected after infection with lab-attenuated or vaccine strains [122]. Abundant expression of the RABV P-protein, a major IFN antagonist of RABV in astrocytes [115,149-154], suggests that inhibition or delay of innate immune responses in astrocytes may be a hallmark of pathogenic field RABV pathogenesis. Accordingly, nonabortive infection of astrocytes by pathogenic field RABV may critically influence the CNS microenvironment, including, for example, a failure to permeabilize the BBB upon infection, which has been linked to contribute to lethal disease progression. In summary, RABV infection of immune and neuron-regulatory astroglia strongly depends on the viral strain, and RABV pathogenesis may depend on the ability to abortively or productively infect these cell types in the brain.

\subsubsection{Microglia}

While activation of microglia has been observed during RABV infection in vitro and in vivo [155-159], the detection of viral antigen in infected microglia in vivo has been assumed to be the result of microglial phagocytosis of infected neurons [128]. Ray and colleagues provided some evidence that human microglia are susceptible to RABV infection in vitro [127]. Recently, the susceptibility of human induced pluripotent stem cell-derived microglia-like cells in vitro has been questioned [160]. Thus, more research is necessary to assess whether microglia productively support RABV infection.

\subsubsection{Oligodendrocytes}

Like microglia, oligodendrocytes represent another comparatively small population of glial cells [161]. In contrast, oligodendrocytes are highly vulnerable to cytotoxic byproducts, such as reactive oxygen species (ROS), high iron content, high glutamate concentrations, and high ATP concentrations [85]. However, little is known about the role of oligodendrocytes during RABV infection. Recent advances with monosynaptic viral RABV tracers have demonstrated occasional oligodendrocyte infection [161,162].

\subsubsection{Schwann Cells}

Whereas awareness about the role of CNS neuroglia in RABV pathogenesis has increased in the last years, a contribution of peripheral neuroglia such as SCs may have not been considered adequately. SCs are highly immunocompetent and exert key functions in immune regulation by antigen presentation, pathogen detection, and cytokine production $[163,164]$. Although release and virion accumulation between axonal and SC membranes as well as nodes of Ranvier has been demonstrated by electron microscopy, until recently, SCs were considered unsusceptible to lyssavirus infection [165,166]. A recent three-dimensional immunofluorescence imaging approach for high-volume tissue imaging [167], however, has enabled the detection of RABV-infected SCs in peripheral nerves after field RABV infection of mice via the natural (intramuscular) and an artificial (intracranial) inoculation route. Accordingly, a model has been suggested in which the infection of peripheral SCs suppresses glia-mediated innate immunity and delays antiviral responses to field virus infections [123].

\subsection{HSV Tropism}

Herpesviruses are pantropic, causing lytic infection in various tissues and cell types in vitro. In humans, herpes labialis is caused by HSV-1 infecting epithelial cells of the orolabial mucosa, followed by virus uptake and transport from closely adjacent axons of sensory nerve endings to ganglia of the PNS. Further, HSV-1 is able to infect the corneal or 
genital mucosal epithelium, causing herpes genitalis or herpes keratitis, respectively [168]. Once in the PNS, HSV-1 establishes lifelong latency within the sensory and autonomic peripheral ganglia of the head and spinal cord. It can be periodically reactivated by various stimuli $[169,170]$.

HSV-1 tropism to the frontal and temporal lobe has been discussed given the respective invasion route and synaptic connections by which the virus may reach the brain, the olfactory and trigeminal nerve [171]. Thus, direct connections from the PNS to the CNS facilitate invasion towards the brain across synapse-linked neurons. However, detailed research is still needed on that point, especially on why HSV-1 maintains the devastating potential to reach the CNS in rare cases, but otherwise resides latently in peripheral ganglia [172]. Moreover, it is not yet clear whether HSV-1 reaches the CNS directly after primary infection, which leads to encephalitis, or whether this happens after reactivation of the virus in latent infected tissue [44]. This is in contrast to rabies, which is always virulent and invariably fatal when entering the nervous system [50].

\subsubsection{Astrocytes}

Apart from neurons, glial cells have been shown to be permissive to HSV-1 infection $[173,174]$. Lokensgard and colleagues reported that astrocytes are highly susceptible to productive HSV-1 infection and fail to produce cytokines upon infection $[173,174]$. Other studies, however, have reported the upregulation of pathogen recognition receptors, DNA/RNA sensors, IFNs, and IFN-stimulated genes (ISGs) in astrocytes upon HSV-1 infection [175-177]. Upon in vitro and in vivo infection, astrocytes respond to infection with hypertrophy and rounding and syncytia formation [178-180].

\subsubsection{Microglia}

In microglia, HSV-1 infection does not result in productive viral replication, but instead in the production of significant amounts of proinflammatory cytokines [181]. In HSV-1 infected brains, microglia are present around cell bodies and dendrites of neurons before mature viral particles are detectable [182].

\subsubsection{Oligodendrocytes}

Apart from astrocytes, human oligodendrocytes have been shown to be variably permissive to HSV-1 infection in vitro $[183,184]$. However, in HSV-1 infected mice, HSV-1 antigen-positive oligodendrocytes have been found in the spinal trigeminal tract [185]. In line with this, the occurrence of demyelinating lesions in rodents supports the susceptibility of oligodendrocytes to HSV-1 infection [186].

\subsubsection{Schwann Cells}

It has been shown that murine SCs can be infected after intraocular inoculation, but produce no viral progeny, whereas direct inoculation into the sciatic nerve leads to productive HSV-1 infection [187]. In another study, infection of SCs was demonstrated only at late time points after infection, confirming the notion that these cells (i) are not the primary target of HSV-1 and (ii) do not play a role in retrograde transport upon neuroinvasion. Thus, it is very likely that SCs become infected via productive infection of the neuronal cell body, the subsequent escape of HSV-1 along axons, and the emergence into associated SCs along the nerve tract [188]. Similar to SCs, the infection of satellite cells seems to be abortive since only empty capsids have been detected by electron microscopy of chicken dorsal root ganglia [189]. In line with this, very limited infection has been reported in satellite cells from mouse and human dorsal root ganglia $[190,191]$.

Taken together, RABV field strains and HSV-1 productively infect neurons and astrocytes in vivo, while microglia and oligodendroglia are less or not at all susceptible to infection. Infection of SCs has been observed for field RABV and HSV infection, but the role of infected SCs in viral encephalitis remains poorly understood. On the one hand, the strain specificity of the virus and, on the other hand, receptor expression and cell-specific 
immune responses of the cellular host determine cellular tropism and infection outcome. Although it is suggested that RABV and HSV bear a neuron-specific tropism, cellular tropism might be much wider than initially believed (Figure 3).

\section{CNS}

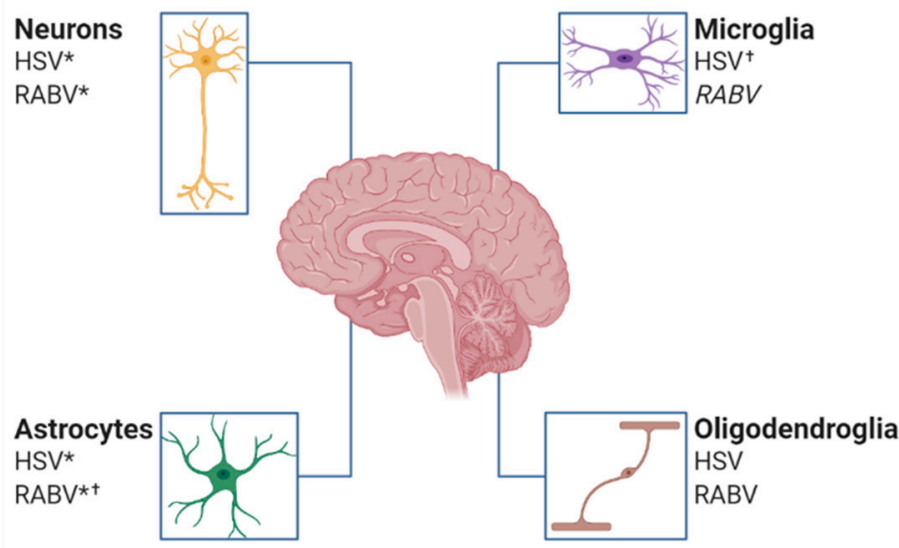

PNS

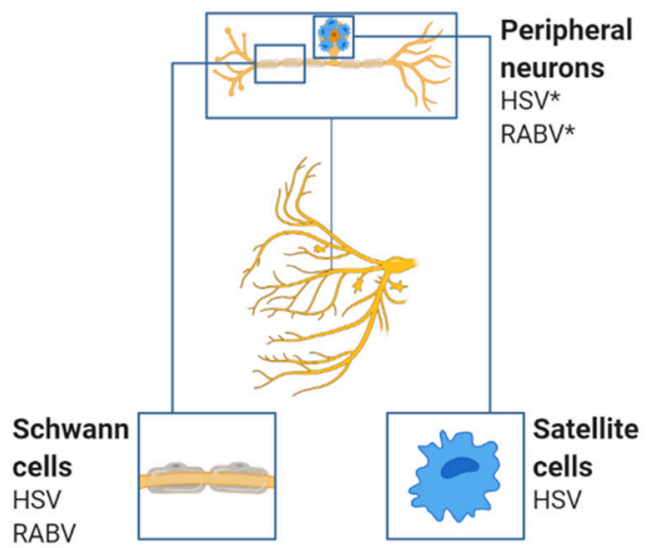

Figure 3. Cellular tropism of RABV and HSV in the CNS and PNS. Both RABV and HSV infect a variety of cells in the CNS (left) and PNS (right) in both abortive $(\dagger)$ and nonabortive $\left(^{*}\right)$ manners. If neither has been demonstrated thus far or productive infection can vary, no indicator is assigned. An abortive infection is defined by the inability of an infected cell to generate infectious progenitor virus, but it can still result in the activation of (innate) immune mechanisms. For RABV, a strain-specific ability of pathogenic RABV to nonabortively infect murine astrocytes in vivo has been demonstrated [122]. Positive viral antigen staining has been demonstrated to occur in neurons, astrocytes, and oligodendrocytes of postmortem human brain tissues [192], whereas infection of SCs has thus far only been shown in a mouse animal model [123]. Fetal human microglia have only stained positive for RABV antigen in vitro (italics) [127]; however, the susceptibility of human induced pluripotent stem cell-derived microglia-like cells has been questioned recently [160]. In postmortem human brain tissues, neurons, astrocytes, and oligodendrocytes have stained positive for HSV antigens [173], whereas infected SCs have only been demonstrated in a mouse animal model [187]. Microglia are supposedly not permissive to HSV infection [182,193].

\section{The Role of the Blood-Brain Barrier in HSV and RABV Infections}

Blood vessels vascularizing the CNS deliver oxygen and nutrients to the nervous tissue, analogous to blood vessel functions in peripheral organs. Apart from this, however, the BBB possesses unique properties allowing the precise control of molecule and cell movements between the blood and the brain. Physiological barrier properties are mediated by ECs, which are tightly regulated by vascular, immune, and neural cells. The main function of the BBB is the protection of neural tissue from toxins and pathogens [3]. Conversely, alterations of BBB functions endanger CNS homeostasis and are implied in numerous neurological diseases, such cerebral ischemia, brain trauma, brain tumors, and brain infections [194].

\subsection{Rabies Virus}

Infection of nerve endings and retrograde axonal transport enables RABV to bypass the neuroprotective BBB, which normally restricts viral entry [195]. Subsequently, RABV benefits from the immunologically quiescent neural environment of the CNS [196]. More importantly, viral protein-mediated sequestration of the immune response, especially its antagonism against early IFN response, enables RABV to successfully replicate inside the CNS $[119,197]$. RABV-mediated sequestration of the host immune response hinders the opening of the BBB, leading to lethal RABV infection [198-200]. Accordingly, Roy and colleagues showed that mice infected with the lethal SHBRV develop a fully functional immune response in the periphery, while immune cells are unable to migrate to the infected CNS [201]. As a consequence of deficits in increasing the BBB permeability in the cerebellum, immune effector cells and associated virus-neutralizing antibodies cannot reach the CNS for RABV clearance [113,114,202]. However, the exact mechanisms linking 
RABV-mediated sequestration of the host immune response to the failure to open the BBB remain to be elucidated.

Even though an effective therapy for rabies is still missing, studies have reported the survival of a few RABV patients with acute illness [203-207]. One of the main findings associated with nonlethal RABV infection is the presence of virus-neutralizing antibodies in the serum or CSF of RABV survivors [208,209]. In mice, crossing of virus-neutralizing antibodies through a permeable BBB protects against lethal RABV infection $[199,210]$. By comparing mice with different genetic backgrounds, Roy and Hooper showed that the opening of the BBB is of utmost importance to the clearance of RABV from the infected CNS [198]. Accordingly, SJL mice known to develop more extensive CNS inflammation due to the increased recruitment of infiltrating IL-10 producing CD4 ${ }^{+}$cells $[211,212]$ more often survive wt bat RABV infection compared with other mouse strains $[213,214]$. In contrast, $129 / \mathrm{SvEv}$ mice succumb to infection with SHBRV due to the failure of opening the BBB [200]. To increase BBB permeability, SJL mice were immunized with myelin basic protein to induce experimental allergic encephalomyelitis prior to SHBRV infection. Immunized and infected mice showed higher survival rates compared with nonimmunized and infected mice. Vice versa, mice with reduced BBB permeability after treatment with the steroid hormone dehydroepiandrosterone presented higher morbidity, pointing out that the infiltration of immune effector cells across the BBB is critical to survive RABV infection [198]. Emphasizing the importance of immune-response-stimulating agents, intracerebral administration of recombinant RABV expressing the granulocyte-macrophage colony-stimulating factor (LBNSE-GM-CSF) protected more mice from developing rabies compared with the administration of UV-inactivated LBNSE-GM-CSF. LBNSE-GM-CSF infection led to significantly higher levels of chemokine and cytokine expression and more infiltrating immune cells in the CNS than UV-inactivated LBNSE-GM-CSF. Additionally, direct administration of immune-response-stimulating agents to the CNS enhanced BBB permeability and infiltration of immune cells, consequently preventing the development of rabies [198]. Overall, the failure of opening the BBB during RABV infection enables the virus to successfully replicate in the tightly controlled immunosuppressive micromilieu of the CNS. Clearance of RABV from the CNS requires RABV-specific immunity, such as the presence of circulating virus-neutralizing antibodies and the enhancement of BBB permeability, to allow immune effectors to access the CNS. Concomitant peripheral and intracerebroventricular administration of the two potent neutralizing monoclonal antibodies, RVC20 and RVC58, directed against the viral G-protein cured symptomatic rabid mice $[215,216]$. Antibody-based therapeutic approaches remain a promising treatment to treat neurological symptoms and cure symptomatic rabies.

\subsection{Herpes Simplex Virus}

In contrast to rabies, the disruption of the BBB is a crucial pathological mechanism in the development of HSE, which has been recently reviewed in detail [217]. Brain damage is mediated by lytic infection of neurons and glial cells as well as by neuroinflammatory processes [218]. Toll-like receptor (TLR)-dependent recognition of HSV-1 by neurons and glia leads to the initial production of cytokines, such as type I IFN, IL-6, IL-1 $\beta$, IFN- $\gamma$, and TNF, resulting in the disruption of the BBB [219]. Consequently, immune cells are recruited to the brain parenchyma, resulting in an enhanced inflammatory response to HSV-1 infection and increased neuronal damage. In vivo, $\mathrm{CD}^{+}$or $\mathrm{CD}^{+} \mathrm{T}$ cells and macrophages are present in perivascular infiltrates close to HSV-infected cells in the murine brainstem [220]. In addition, vasogenic edema and hemorrhage may occur [217]. In general, leukocyte entry into the CNS is regulated by several factors, including the expression of adhesion molecules (PECAM, CD99, VE-cadherin, and JAM-A, B, and C) [221], expression of matrix metalloproteinases (MMPs) [222,223], and endothelial expression of chemokines (CCL2, CCL5, CXCL10, CXCL8) [224]. Briefly, HSV-1 affects the structure and function of the BBB, likely via inflammatory-induced activation [225] and direct infection of ECs [226,227]. More specifically, HSV-1-induced increase in ICAM-1 expression on ECs mediates an increased 
interaction between ECs and circulating leukocytes and subsequently leads to infiltration of immune cells into the brain parenchyma [225,227]. Very recently, it could be demonstrated that HSV-1 alters the Golgi structure in ECs of the BBB and thus reduces the integrity of the same [228]. Further, MMPs that are thought to cleave tight junction proteins of the BBB are significantly upregulated in HSV-1-infected humans and mice. High levels of MMP2 and MMP9 have been shown to play a pivotal role in BBB damage in HSE [229] and other brain infections, such as West Nile virus encephalitis [230]. ROS, which are increasingly produced by microglia in HSE, are both beneficial and disadvantageous. On the one hand, they prevent the further spread of the pathogen; on the other hand, they degrade tight junction proteins and thus increase the permeability of the BBB [231].

However, how HSE-associated ROS alters tight junction integrity urges further research. CCL2, a major chemokine in CNS inflammation, also plays an essential role in the regulation of the BBB permeability, endothelial dysfunction, and increased leukocyte recruitment [232]. Different molecular pathways include the reorganization of the actin cytoskeleton of ECs mediated through the interaction between CCL2 and its receptor CCR2 [233] or the disruption of adherens junctions by Src-kinase-dependent phosphorylation of $\beta$-catenin [232]. Dysfunction of the BBB can also be caused by astrocyte disturbances. HSV-1 has been reported to increase the expression of aquaporin 4 (AQP4) on astrocytes, which regulates water transport across the BBB [234]. An increase in AQP4 leads to water influx into astrocytes and the basement membrane, indirectly leading to the disruption of the BBB [235]. In addition, this mechanism leads to intracellular or extracellular brain edema, which is associated with a high mortality in HSE patients [236]. Furthermore, HSV-1 infection of astrocytes leads to apoptosis through the interaction between the virus and mitochondria, resulting in the destruction of the BBB [217].

Whether reactive astrocytes are beneficial in HSE remains under debate. In an HSE mouse model for chronic inflammation, it was demonstrated that astrogliosis occurs acutely and chronically after infection and is associated with a persistent inflammatory, potentially harmful reaction [237]. In contrast, reactive astrocytes are able to release vascular protective factors, which promote the repair of the $\mathrm{BBB}$, thereby decreasing the expression of endothelial surface receptors and leukocyte infiltration [238]. In summary, HSV-1 infection of the brain, in contrast to RABV infection, leads to compromised BBB function and subsequently to a fulminant immune response, whose neuroprotective versus neurodestructive properties have yet to be defined.

\section{Differences in Cell-Type-Specific Innate Immune Responses between RABV and HSV Infection in the CNS}

The innate immune system represents the first line of defense against viral invaders. Germline-encoded pattern recognition receptors (PRRs), such as TLRs and retinoic acidinducible gene I (RIG-I)-like helicases (RLRs), sense evolutionary conserved pathogenassociated molecular patterns and danger-associated molecular patterns [239]. Further, attention has recently been drawn to cytosolic PRRs, which sense cytosolic DNA, such as cGAS, gamma-interferon-inducible protein (IFI16), and absent in melanoma 2 (AIM2) [240]. All major glial cells, more specifically astrocytes, microglia, oligodendrocytes, and SCs, as well as neurons, express a different repertoire of PRRs including TLRs. In detail, TLR2 and TLR9 are expressed by microglia and astrocytes, whereas TLR3 is found in microglia, astrocytes, oligodendrocytes, and neurons [175,241,242]. Further, RLR RIG-I and melanoma differentiation-associated protein 5 (MDA5) are present in microglia, astrocytes, and neurons [243]. Apart from differences observed in the expression of PRRs between the distinct CNS cell types, PRR expression varies tremendously due to its tight regulation by the cellular differentiation status, the inflammatory processes, and the presence of pathogens [244]. Generally, viral recognition via PRRs leads to an early IFN response, which restricts viral growth. Another essential function of the innate immune system is to prime and initiate an adaptive immune response [245]. Compared with glial cells, it is thought that neurons may lack robust innate immune signaling to avoid damage to this largely irreplaceable and nonrenewable cell population [246]. Overall, distinct cell- 
specific innate immune responses to viral infection may account for viral tropism and pathophysiological findings, such as a rather quiescent versus fulminant inflammatory response (Figure 4).

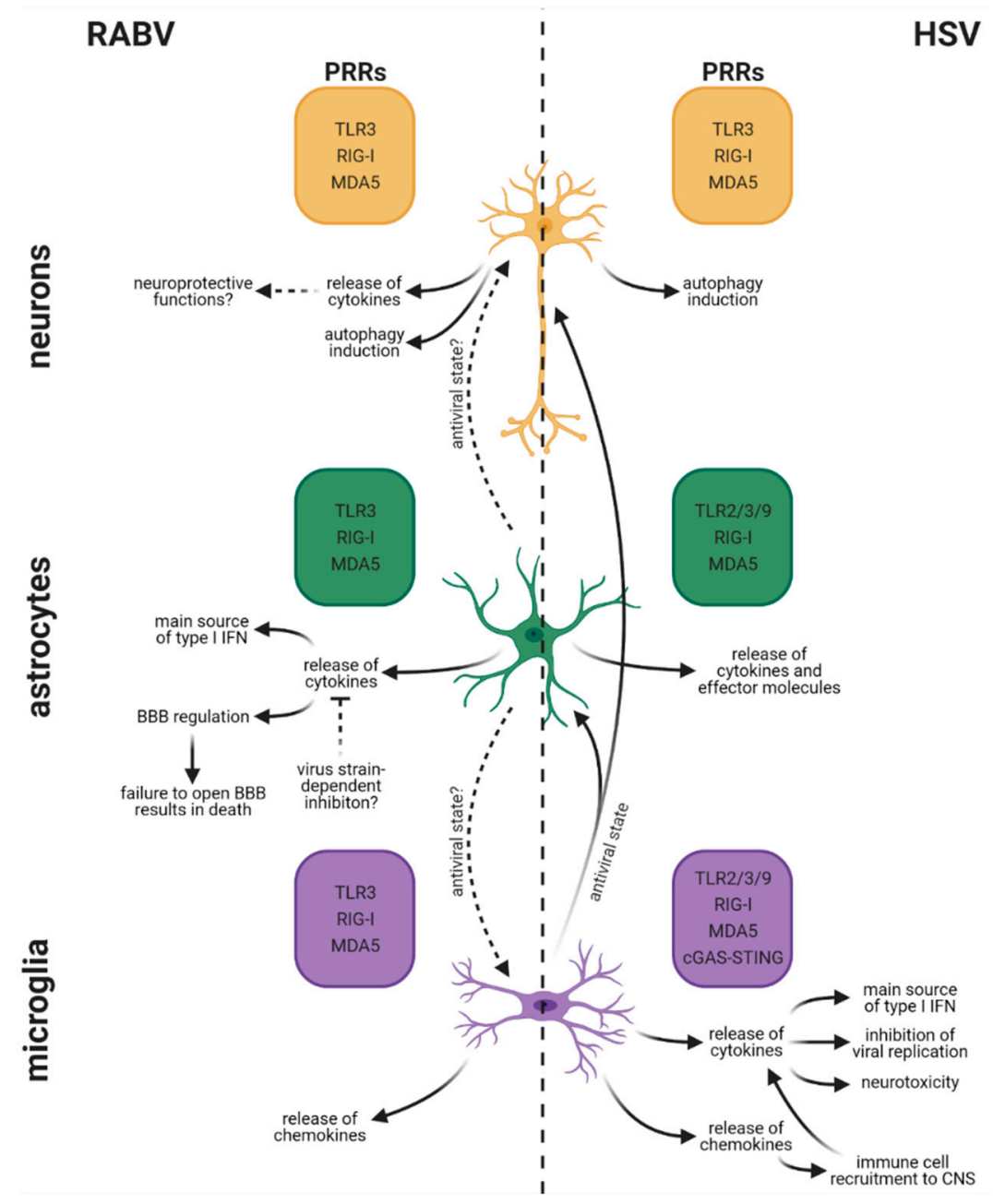

Figure 4. Hypothesis of cell-specific innate immune responses of CNS cell types upon RABV and HSV infection. Neurons (yellow), astrocytes (green), and microglia (purple) are productively or nonproductively infected by HSV and RABV (Figure 3). Infection is sensed via a cell-specific set of PRRs, which trigger downstream signaling pathways and lead to the induction of an innate immune response [239]. Whereas certain PRRs are associated with RABV and HSV infection, neurons do not exhibit evident immune responses upon viral infection. It is suggested that neurons lack robust innate immune signaling to minimize harm and rather require autophagy to restrict RABV [247] and HSV [246,248] replication. In contrast, astrocytes and microglia respond to RABV and HSV infection via the production of cytokines and chemokines [109,144,193,249-253]. While for HSV, microglia are the main source of type I IFN in the CNS and result in pronounced immune cell infiltration [108], astrocytes comprise the primary type I IFN producers for RABV [109]. Dashed arrows indicate putative or suggested effects.

\subsection{Rabies Virus}

RABV is immediately recognized by the innate immune system after the virus is exposed to the skin or muscle by bites or scratches. Innate PRRs sense RABV at first in the periphery and afterwards in the CNS [254]. Intracellularly, RABV is recognized via MDA5 and RIG-I [109,144,255], TLR3 [256-258], or TLR7 [259-261], consequently leading to the activation of the NF- $\mathrm{KB}$ (nuclear factor 'kappa-light-chain-enhancer' of activated B-cells) pathway and the secretion of type I IFNs [245]. 
After cellular recognition of RABV by the innate immune system, macrophages play crucial roles in the uptake of pathogens via specialized endocytic mechanisms [262]. Lytle and colleagues observed that after rabies immunization, macrophages accumulate at the entry site [263] probably due to the chemokine-mediated recruitment of circulating monocytes. Like macrophages, dendritic cells (DCs) also efficiently ingest circulating pathogens and display antigens to prime adaptive immune responses [262]. Infection with lab-attenuated RABV leads to the RIG-I-dependent activation of DCs and subsequent production of type I IFNs [255,264]. In contrast, binding and entry into DCs by wt RABV is severely blocked, and infection does not efficiently induce DC activation [265]. Despite the inability of DCs to activate T cells during wt RABV infection, activated $\mathrm{CD} 69^{+} \mathrm{T}$ cells can be found in the draining lymph nodes and peripheral blood of infected mice, independent of the virulence of the RABV strain $[198,266]$.

Once the virus enters the CNS, RABV triggers innate immune responses of neurons [256], astrocytes [109,144], and microglia [109,249], which mount primary (activation of NF- $\mathrm{kB}$ ) and secondary IFN responses (activation of Janus kinase-signal transducers and activators of transcription (JAK-STAT)), inducing the production of ISGs, such as cytokines and chemokines [245]. However, the extent of immune responses triggered strongly depends on the cell type [109] and the viral strain used [114,122,144,267]. Cytokines and chemokines are crucial to recruit peripheral immune cells to the CNS, since both favor changes in BBB permeability, which in turn regulates the contact between circulating immune cells and the neural tissue [101]. Since wt RABV stimulates little or no inflammatory response, recruitment of peripheral cells to the CNS is limited [200,201].

\subsubsection{Neurons}

TLR3 is involved in RABV pathogenesis $[257,268]$ and is expressed by glial cells and neurons [88]. Upon RABV infection, human neuronal NT2-N cells upregulate TLR3 expression in vitro after challenge with the RABV strain CVS, possibly due to sensing of viral dsRNA. TLR3, subcellularly located in endosomes, senses endocytosed dsRNA [269]. In a human neuroblastoma cell line, CVS infection leads to the localization of TLR3 in spherical perinuclear structures [257] called Negri bodies (NBs), which represent active RABV replication sites $[270,271]$. Together with enhanced TLR3 expression in cerebral cortical tissues in rabies patients [258], this leads to the hypothesis that RABV inactivates the physiological function of TLR3 as a viral sensor and exploits the protein to help the spatial arrangement of RABV-induced NBs to support viral replication [257,271]. Additionally, taking into account that TLR3 can mediate neuronal apoptosis [272], sequestration of TLR3 might allow RABV to escape TLR-mediated apoptosis. Further, Peng and colleagues provide evidence that wt RABV induces autophagy, which can in turn decrease apoptosis in neuroblastoma cells in vitro [247]. During RABV neuroinvasion, RABV limits apoptosis and inflammation to ensure the integrity of the neuronal network, subsequently enabling RABV transport throughout the CNS [117]. Following CVS infection, human neuronal NT2-N cells strongly upregulate the expression of IFN- $\beta$, CCL5, CXCL10, IL-6, TNF, and IL-1 $\alpha$ [256]. There is increasing evidence stating that IFN- $\beta$ [273], CCL5 [274], and IL-6 $[275,276]$ also harbor neuroprotective functions. Despite the onset of rabies-induced neurological signs and symptoms, histological lesions stay relatively mild in the RABVinfected CNS [277]. Apoptosis has been reported in neuronal cells when infected by RABV, and several mechanisms have been investigated [278-281]. Although necrosis of several areas might appear sporadically in the brain of human rabid patients [112,282], neuronal necrosis in RABV-infected mice is highly restricted and depends on the viral strain used for infection experiments [283-285]. Apart from necrosis, apoptosis is strongly limited in RABV-infected murine, canine, and human brains [192]. Still, neurons exhibit marked beading and fragmentation of dendrites and axons, as well as swollen mitochondria in perikarya and proximal dendrites in the CVS-infected murine cerebral cortex [286]. Although we are far from fully understanding cellular death pathways involved in rabies 
pathogenesis, it is believed that both structural changes of neurons [286] and neuronal dysfunction [24] can explain the fatal outcome of rabies rather than neuronal cell death.

\subsubsection{Astrocytes}

Dependent on the virus strain, astrocytes can support RABV infection in vitro and in vivo [122]. In general, astrocytes have higher expression levels of ISGs, rendering them less susceptible to viral infections than other cell types [287]. There is growing evidence that inflammatory upregulation of TLR3 expression in human astrocytes results in neuroprotection [288]. However, the role of TLR3-mediated signaling in astrocytes during RABV infection is still unknown. Besides TLRs, RLRs represent another group of PRRs, which sense RABV [109] and consequently trigger antiviral responses via the activation of NF-KB and JAK-STAT pathways [289]. The RLRs MDA5 and RIG-I are cytoplasmic viral sensors, which recognize viral replication via recognition of dsRNA, resulting in MAVS-mediated IRF3 activation [264]. In astrocytes, lab-attenuated RABV produces higher levels of dsRNA compared with wt RABV. As a result, lab-attenuated RABV induces MDA5/RIG-I-mediated activation of MAVS/p38/NF- $\mathrm{kB}$ to a higher degree than wt RABV. Consequent production of ISGs and inflammatory cytokines leads to the clearance of labattenuated RABV from astrocytes. In contrast, wt RABV nonabortively infects astrocytes through the evasion of the MDA5/RIG-I sensory pathway [144]. Primary murine astrocytes respond with the expression of IL-6 and TNF to VSV infection, a rhabdovirus that closely resembles RABV. In contrast, heat-inactivated VSV robustly lowers astrocyte-mediated cytokine expression, viral replication, and sensing of viral RNA by RLRs [290]. Overall, RLRs play a crucial role for RABV sensing and initiating cytokine production in infected astrocytes; however, more experimental data are needed to confirm this hypothesis.

In vivo, astrocytes induce IFN- $\beta$ production via RLR and TLR signal transduction pathways, representing the main source of IFN- $\beta$ in the virus-infected brain [109]. For other neurotropic virus infections, astrocytes have also been implicated as the main type I IFN producers in the CNS [110,111]. Moreover, lab-attenuated RABV induces the expression of a variety of inflammatory cytokines (TNF, IL-6, IL-1 $\beta$, IFN- $\gamma$, IL-17, and VEGF) in astrocytes, which in turn regulate BBB permeability [144]. Generally, astrocytes are also known as innate immune neuroglia releasing a variety of neurotrophins and proand anti-inflammatory mediators (e.g., TGF- $\beta$, IL-1 $\beta$, IL-6, CXCL10, CXCL12), enabling the communication with neighboring cells and recruiting adaptive immune cells to the CNS [101]. Interestingly, it has been shown that pathogenic field RABV infection strongly modulates microRNA (miRNA) expression in the brains of infected mice. Predicted targets of RABV-modulated miRNAs involve the TGF- $\beta$ signaling pathway [291], which is strongly associated with astrocyte scar formation [292]. Other targets of RABV-modulated miRNAs include the JAK-STAT signaling pathway (especially JAK2), suppressor of cytokine signaling (Socs3), and Socs4 [291]. It is well known, that the JAK2-STAT3 pathway plays a central role in astrocyte reactivity upon multiple pathological conditions [293], making them a possible target of RABV-modulated miRNAs.

\subsubsection{Microglia}

Besides immunologically active astrocytes, microglia respond to infection via expression of ISGs, chemokines, and proinflammatory cytokines [263]. In detail, macrophagemediated endocytosis of inactivated and infectious RABV virions activates the extracellular signal-regulated kinases $1 / 2$ (ERK1/2) signaling pathways, ultimately leading to chemokine expression [294]. Chemokine secretion mediates leukocyte recruitment into the CNS in a multistep process [295]. Not only RNA levels of CXCL10 and CCL5 in the RABV-infected murine microglial cells Ra2 are approximately 3000 -fold higher compared with mock-infected cells, but also protein levels increase steeply, reaching a plateau phase at $20 \mathrm{~h}$ postinfection. Furthermore, the expression of CCL5 and CXCL10 is modulated upon RABV replication since UV-inactivated virions do not trigger chemokine expression [249]. Emphasizing the importance of the mitogen-activated protein kinase (MAPK) subfamilies 
p38, c-Jun N-terminal kinases (JNK), and ERK $1 / 2$ in the establishment of an antiviral response against RABV [294,296], Nakamichi and colleagues discovered that RABV triggers phosphorylation of MAPK signal transduction pathways in murine microglia, possibly triggering chemokine secretion [249]. Interestingly, activation of p38 and ERK1/2 signal transduction pathways stimulates CXCL10 expression, whereas CCL5 expression is positively regulated by $\mathrm{p} 38$ and negatively regulated by ERK1/2. Particularly p38 is required for the NF-kB-mediated expression of CXCL10 and CCL5 [249], chemokines known to act as proinflammatory mediators during viral encephalitis [297-300]. Apart from the secretion of cytokines and chemokines, microglia also produce important amounts of type I IFN during RABV infection [109].

\subsection{Herpes Simplex Virus}

HSV-1 infection is controlled by both the innate and adaptive immune system and is initially recognized by TLR2, TLR3, and TLR9 [301]. While HSV glycoproteins are sensed by TLR2 on the cell surface, viral DNA is detected by endosomal TLR9, followed by the activation of cGAS and the adaptor protein STING. Besides TLRs, RLRs, including RIG-I and MDA5, are described to detect HSV-1 RNA in the cytoplasm of infected cells, leading to the activation of the MAVS adaptor, NF- $\mathrm{kB}$, activator protein 1 (AP-1), and IFN regulatory factors (IRFs) such as IRF3 and IRF7. These molecules act as transcription factors, which result in the production of proinflammatory cytokines and type I IFN [302], triggering the initial response to HSV-1 infection [303]. IFN- $\alpha$ and IFN- $\beta$ signal through the interaction with interferon receptors (IFNAR) 1 and 2, resulting in the subsequent activation of the JAK-STAT signaling pathway [304]. More specifically, it has been shown that the DNAdependent RNA polymerase III (Pol-III) is responsible for transcribing cytosolic viral DNA into an RNA ligand that binds to RIG-I, resulting in the induction of IFN- $\beta$ upon HSV-1 infection [305]. In the CNS, HSV-1 is mainly recognized by microglia and astrocytes.

The immune response in HSE has been described as a 'double-edged sword'. It is crucial to control viral replication early after infection, as otherwise an uncontrolled immune response can lead to excessive reactions that can be fatal for the host [306]. The first-line viral defense is mediated by the TLR2 receptor driving the expression of various interleukins, type I IFN, and TNF [307]. However, since mice lacking TLR2 have revealed higher survival rates after HSV-1 infection than the wt strain, the TLR2-mediated response can have detrimental effects on the outcome of HSE [308]. In contrast to TLR2, TLR9 does not play a major role in the fight against HSV-1 [309], but rather functions simultaneously with TLR2 by recruiting natural killer (NK) cells to the CNS [310,311]. For the control of HSV-1 replication and the production of type I and II IFNs in the brain, TLR3-mediated sensing of HSV-1 has been described as extremely important [312]. Apart from TLR3, the cytosolic PRRs RIG-I and DNA-dependent activator of interferon regulatory factor (DAI) have been shown to restrict HSV-1 replication [313,314]. Unlike HSV-1, wt RABV successfully evades TLR3 signaling, thereby inhibiting the induction of IFN $[257,271]$.

\subsubsection{Neurons}

Neurons are highly susceptible to HSV infection. Lafaille and colleagues provide strong evidence that neuronal induction of IFN- $\beta$ and/or IFN- $\gamma$ is highly dependent on UNC-93B, which is associated with TLR-mediated responses [315]. Further, UNC-93Bdeficient human neurons exhibit impaired IFN- $\beta$ and IFN- $\gamma$ responses to HSV-1 infection and are more susceptible to HSV-1 infection [315]. Although secretion of IFNs impairs HSV-1 replication in iPSC-derived human neurons [315], type I IFN treatment fails to completely block HSV-1 replication in murine neurons [246]. Similar to RABV, autophagy, not IFN signaling, is suggested to be the dominant antiviral strategy employed by neurons to control HSV infection $[246,248]$. Using an in vitro system of purified TG neurons from adult mice grown in compartmentalized chambers, Rosato and colleagues showed that the administration of IFN- $\beta$ at either the soma or the axon is capable of restricting HSV-1 replication. Moreover, they showed that non-neuronal IFN signaling is insufficient to 
control HSV-1 dissemination and mortality in vivo, whereas neuronal IFN signaling alone is necessary to control HSV-1 replication, disease, and survival [316]. Recently, studies have highlighted the importance of the neuronal differentiation state and subtype on antiviral signaling capabilities [317-319]. Thus, different models and differentiation states might explain differences observed in the role of the neuronal type I IFN response. Taken together, neurons might restrict HSV replication via the induction of autophagy $[246,248]$ and type I IFNs [315,316].

\subsubsection{Astrocytes}

Astrocytes have not been intensively studied in HSV-1 brain infection. Recently, the expression of TLRs in response to HSV-1 infection in astrocytes has been investigated in more detail [175]. Mainly TLR2, TLR6, TLR7, TLR8, and TLR9, as well as DAI, cGAS, and MDA5, are upregulated by astrocytes, while IFI204, which senses nuclear DNA, is downregulated, implicating a potential viral immune evasion strategy. Upon infection, astrocytes react with the production of type I and II IFNs, which in turn activate the JAK-STAT pathway. Especially STAT4 expression is increased, which may stimulate the proinflammatory IL-12 cascade. In addition, different ISGs have been identified, which elicit antiviral properties in response to HSV-1 infection of astrocytes, such as RNase L, PKR (protein kinase R), IFIT (interferon induced proteins with tetratricopeptide repeats), and viperin. In contrast to microglia, astrocytes do not produce any neurotoxic substances [320]. Moreover, TLR3 expression in astrocytes is necessary to respond to neurotropic HSV-2 infection with the induction of IFN- $\beta$ production possibly preventing viral spread [252].

\subsubsection{Microglia}

Cytokines produced by glial cells play a crucial role in the activation of glia in the CNS itself and in the attraction of immune cells, such as DCs, NK cells, and lymphocytes, to the brain [253]. Specifically, human microglia produce high amounts of CCL5, CXCL10, TNF, and IL-1 $\beta$ as well as lower amounts of IL-6, IL-8, CCL3, CCL4, and CCL2 in a TLR3-dependent manner [193]. Similar to astrocytes in RABV pathogenesis, microglia are the main source of type I IFN in HSE [108]. Those glial cell-produced factors reveal variable antiviral properties in vitro. Whereas TNF drastically limits viral replication in astrocytes, IL-1 $\beta$ decreases viral replication comparatively little. In neurons, however, TNF and IL-1 $\beta$ have no effect on viral replication, whereas CXCL10 drastically decreases HSV-1 replication [193]. For HSV-1, it could be shown that microglia transfer its antiviral response to neurons and astrocytes [108]. Through the expression of IFN- $\alpha$, microglia upregulate specific TLRs such as TLR3, TLR4, and TLR7 on DCs, NK cells, and lymphocytes, and thus increase the production of IFN and cytokines [253]. Specifically, CCL5, CCL2, and CXCL10 recruit peripheral immune cells to the infected brain [321-323], of which CXCL10 in particular has been shown to attract lymphocytes to HSV-1 infection [193]. Microglial IFN- $\beta$ further mediates the production of IL-10, a known immunosuppressor, which can prevent severe inflammation [324], and IL-6, which protects against neuronal loss [325]. Cytokines and chemokines primarily originating from microglia also feature neurotoxic activity as it has been reported for TNF and IL-1 $\beta$ [193]. HSV-1-infected microglial cells have been shown to produce ROS, leading to higher amounts of inducible nitric oxide synthase and cytotoxic nitric oxide, which are responsible for brain damage [250]. Microgliamediated immune responses can also have detrimental long-term consequences. Chronic HSV-1 infection leads to persistent activation of microglia [251], resulting in prolonged upregulation of ISGs, reinforcing chronic inflammation and neuronal damage [326].

\section{Future Directions}

Even though the CNS remains a highly vulnerable tissue for a few specialized viral diseases, such as rabies and HSE, little is known about the role of glial cells during neuroinvasive infections. Deciphering the underlying mechanisms of highly distinct viral growth characteristics between different CNS cell types may unravel factors that limit viral replication. 
To date, neurotropic RABV is often studied in animal models and neuronal cell types using lab-attenuated viruses. Therefore, data are scarce about the role of non-neuronal CNS cell types during viral encephalomyelitis in humans. Similar to rabies, the roles of astrocytes, oligodendrocytes, and microglia during HSE are still not fully understood. Studying HSV or RABV in neuronal monocultures does not reflect the diversity of the CNS. More importantly, the crosstalk between neurons, astrocytes, oligodendrocytes, and microglia is crucial to ensure CNS homeostasis and to protect the infected CNS from pathological conditions. More sophisticated models, which reflect the human brain in a physiological context, are needed to understand the interaction of HSV and RABV with cell-specific signaling pathways. Thus, determining the molecular mechanisms, which define the cellular susceptibility to neurotropic HSV and RABV infection, remains crucial to discover new and promising therapeutic targets.

Author Contributions: L.F., L.M.Z. and J.S.-E. wrote the manuscript; J.S.-E. performed the histopathology; L.M.Z. generated the figures; L.F., L.M.Z., J.S.-E., S.F. and H.B. reviewed and edited the manuscript. All authors have read and agreed to the published version of the manuscript.

Funding: L.F. was supported by the Pasteur-Paris University (PPU) International PhD Program. FLI work was supported by an intramural collaborative research grant at the Friedrich Loeffler Institute (Ri-0372) to S.F.

Institutional Review Board Statement: Not applicable.

Informed Consent Statement: Not applicable.

Data Availability Statement: No new data were created or analyzed in this study. Data sharing is not applicable to this article.

Acknowledgments: We would like to thank Jean-Marc Cavaillon for his scientific advice, especially his expertise concerning the molecular pathways underlying innate immunity. We highly appreciate the support from Soren Riis Paludan and Line Reinert from Aarhus University, Denmark, who kindly provided tissue sections from HSV-1 infected mice. Figures were created with BioRender.com.

Conflicts of Interest: The authors declare that they have no competing interests.

\section{Abbreviations}

AIM2 = absent in melanoma; AP-1 = activator protein 1; AQP4 = aquaporin 4; $\mathrm{BBB}=$ blood brain barrier; cGAMP = cyclic guanosine monophosphate-adenosine monophosphate; cGAS = cyclic GMP-AMP synthase; $\mathrm{CNS}=$ central nervous system; $\mathrm{COSR}=$ coyote street $\mathrm{RABV} ; \mathrm{CVS}=$ challenge virus standard; $\mathrm{DAI}=\mathrm{DNA}$-dependent activator of IFN regulatory factor; DCs = dendritic cells; ECs = endothelial cells; ERK = extracellular signal-regulated kinase; $\mathrm{g}=(\mathrm{HSV})$ glycoprotein; G-protein $=(\mathrm{RABV})$ glycoprotein; HSE $=$ HSV encephalitis; HSV = herpes simplex virus; HVEM = herpesvirus entry mediator; IFI16 = gamma-interferoninducible protein; IFIT $=$ interferon induced proteins with tetratricopeptide repeats; IFNAR $=$ interferon receptor, IFN = interferon; ISG = interferon-stimulated genes; LAT = latency-associated transcript; LBNSE-GM-CSF = RABV expressing granulocytemacrophage colony-stimulating factor; $\mathrm{M}$-protein $=$ matrix protein; $\mathrm{MAPK}=$ mitogen-activated protein kinase; MAVS = mitochondrial antiviral signaling protein; MDA5 = melanoma differentiation-associated protein $5 ; \mathrm{mGluR2}=$ metabotropic glutamate receptor subtype 2; miRNA = microRNA; MMPs = matrix metalloproteinases; MYH9 = myosin heavy chain 9; $\mathrm{NAChR}=$ nicotinic acetylcholine receptor; $\mathrm{NBs}=$ Negri bodies; $\mathrm{NCAM}=$ neuronal cell adhesion molecule; $\mathrm{NK}=$ natural killer; $\mathrm{N}$-protein = nucleoprotein; PILRA = paired immunoglobulinlike type 2 receptor $\alpha$; PKR = protein kinase R; PNS = peripheral nervous system; PRRs $=$ pattern recognition receptors; p75NTR $=$ low-affinity nerve growth factor receptor; P-protein = phosphoprotein; RABV $=$ rabies virus; RIG-I $=$ retinoic-acid-inducible gene I; RLRs = retinoic-acid-inducible gene I-like helicases; ROS = reactive oxygen species; SCs = Schwann cells; SHBRV = silver-haired bat variant of RABV; STING = stimulator of interferon gene; $\mathrm{TG}=$ trigeminal ganglion; $\mathrm{TLRs}=$ toll-like receptors; $\mathrm{TNFRSF14}=\mathrm{TNF}$ receptor superfamily member 14 ; VSV = vesicular stomatitis virus; $\mathrm{wt}=$ wild-type. 


\section{References}

1. Louveau, A.; Smirnov, I.; Keyes, T.J.; Eccles, J.D.; Rouhani, S.J.; Peske, J.D.; Derecki, N.C.; Castle, D.; Mandell, J.W.; Lee, K.S.; et al. Structural and functional features of central nervous system lymphatic vessels. Nature 2015, 523, 337-341. [CrossRef]

2. Forrester, J.V.; McMenamin, P.G.; Dando, S.J. CNS infection and immune privilege. Nat. Rev. Neurosci. 2018, 19, 655-671. [CrossRef]

3. Daneman, R.; Prat, A. The blood-brain barrier. Cold Spring Harb. Perspect. Biol. 2015, 7. [CrossRef]

4. Spindler, K.R.; Hsu, T.-H. Viral disruption of the blood-brain barrier. Trends Microbiol. 2012, 20, 282-290. [CrossRef]

5. De Bock, M.; Van Haver, V.; Vandenbroucke, R.E.; Decrock, E.; Wang, N.; Leybaert, L. Into rather unexplored terrain-transcellular transport across the blood-brain barrier. Glia 2016, 64, 1097-1123. [CrossRef]

6. Fooks, A.R.; Cliquet, F.; Finke, S.; Freuling, C.; Hemachudha, T.; Mani, R.S.; Müller, T.; Nadin-Davis, S.; Picard-Meyer, E.; Wilde, H.; et al. Rabies. Nat. Rev. Dis. Prim. 2017, 3, 17091. [CrossRef]

7. Smith, G. Herpesvirus transport to the nervous system and back again. Annu. Rev. Microbiol. 2012, 66, 153-176. [CrossRef]

8. Baer, G.M. The Natural History of Rabies, 2nd ed.; Academic Press: New York, NY, USA, 1975; Volume 2, ISBN 0120724014.

9. Fooks, A.R.; Banyard, A.C.; Horton, D.L.; Johnson, N.; Mcelhinney, L.M.; Jackson, A.C. Current status of rabies and prospects for elimination. Lancet 2014, 384, 1389-1399. [CrossRef]

10. Hampson, K.; Coudeville, L.; Lembo, T.; Sambo, M.; Kieffer, A.; Attlan, M.; Barrat, J.; Blanton, J.D.; Briggs, D.J.; Cleaveland, S.; et al. Estimating the Global Burden of Endemic Canine Rabies. PLoS Negl. Trop. Dis. 2015, 9, e0003709. [CrossRef]

11. Watson, H.D.; Tignor, G.H.; Smith, A.L. Entry of rabies virus into the peripheral nerves of mice. J. Gen. Virol. 1981, 56, 372-382. [CrossRef]

12. Murphy, F.A.; Bauer, S.P. Early street rabies virus infection in striated muscle and later progression to the central nervous system. Intervirology 1974, 3, 256-268. [CrossRef]

13. Morimoto, K.; Patel, M.; Corisdeo, S.; Hooper, D.C.; Fu, Z.F.; Rupprecht, C.E.; Koprowski, H.; Dietzschold, B. Characterization of a unique variant of bat rabies virus responsible for newly emerging human cases in North America. Proc. Natl. Acad. Sci. USA 1996, 93, 5653-5658. [CrossRef]

14. Ugolini, G. Rabies virus as a transneuronal tracer of neuronal connections. Adv. Virus Res. 2011, 79, 165-202. [CrossRef]

15. Begeman, L.; GeurtsvanKessel, C.; Finke, S.; Freuling, C.M.; Koopmans, M.; Müller, T.; Ruigrok, T.J.H.; Kuiken, T. Comparative pathogenesis of rabies in bats and carnivores, and implications for spillover to humans. Lancet Infect. Dis. 2017, 18, e147-e159. [CrossRef]

16. Velandia-Romero, M.L.; Castellanos, J.E.; Martínez-Gutiérrez, M. In Vivo differential susceptibility of sensory neurons to rabies virus infection. J. Neurovirol. 2013, 19, 367-375. [CrossRef]

17. Jackson, A.C.; Fu, Z.F. Pathogenesis, 3rd ed.; Elsevier Inc.: Amsterdam, The Netherlands, 2013; ISBN 978-0-12-396547-9.

18. Tang, Y.; Rampin, O.; Giuliano, F.; Ugolini, G. Spinal and brain circuits to motoneurons of the bulbospongiosus muscle: Retrograde transneuronal tracing with rabies virus. J. Comp. Neurol. 1999, 414, 167-192. [CrossRef]

19. Graf, W.; Gerrits, N.; Yatim-Dhiba, N.; Ugolini, G. Mapping the oculomotor system: The power of transneuronal labelling with rabies virus. Eur. J. Neurosci. 2002, 15, 1557-1562. [CrossRef]

20. Morcuende, S.; Delgado-García, J.M.; Ugolini, G.; Delgado-Garcia, J.-M.; Ugolini, G. Neuronal premotor networks involved in eyelid responses: Retrograde transneuronal tracing with rabies virus from the orbicularis oculi muscle in the rat. J. Neurosci. 2002, 22, 8808-8818. [CrossRef]

21. Ugolini, G.; Klam, F.; Dans, M.D.; Dubayle, D.; Brandi, A.M.; Büttner-Ennever, J.; Graf, W. Horizontal eye movement networks in primates as revealed by retrograde transneuronal transfer of rabies virus: Differences in monosynaptic input to "slow" and "fast" abducens motoneurons. J. Comp. Neurol. 2006, 498, 762-785. [CrossRef]

22. Ugolini, G. Advances in viral transneuronal tracing. J. Neurosci. Methods 2010, 194, 2-20. [CrossRef]

23. Dhingra, V.; Li, X.; Liu, Y.; Fu, Z.F. Proteomic profiling reveals that rabies virus infection results in differential expression of host proteins involved in ion homeostasis and synaptic physiology in the central nervous system. J. Neurovirol. 2007, 13, 107-117. [CrossRef]

24. Fu, Z.F.; Jackson, A.C. Neuronal dysfunction and death in rabies virus infection. J. Neurovirol. 2005, 11, 101-106. [CrossRef]

25. Hemachudha, T. Human rabies: Clinical aspects, pathogenesis, and potential therapy. Curr. Top. Microbiol. Immunol. 1994, 187, 121-143. [CrossRef]

26. Hemachudha, T.; Ugolini, G.; Wacharapluesadee, S.; Sungkarat, W.; Shuangshoti, S.; Laothamatas, J. Human rabies: Neuropathogenesis, diagnosis, and management. Lancet Neurol. 2013, 12, 498-513. [CrossRef]

27. Almeida, M.F.; Martorelli, L.F.A.; Aires, C.C.; Sallum, P.C.; Durigon, E.L.; Massad, E. Experimental rabies infection in haematophagous bats Desmodus rotundus. Epidemiol. Infect. 2005, 133, 523-527. [CrossRef]

28. Obregón-Morales, C.; Aguilar-Setién, Á.; Perea Martínez, L.; Galvez-Romero, G.; Martínez-Martínez, F.O.; Aréchiga-Ceballos, N. Experimental infection of Artibeus intermedius with a vampire bat rabies virus. Comp. Immunol. Microbiol. Infect. Dis. 2017, 52, 43-47. [CrossRef]

29. Benavides, J.A.; Velasco-Villa, A.; Godino, L.C.; Satheshkumar, P.S.; Nino, R.; Rojas-Paniagua, E.; Shiva, C.; Falcon, N.; Streicker, D.G. Abortive vampire bat rabies infections in Peruvian peridomestic livestock. PLoS Negl. Trop. Dis. 2020, 14, e0008194. [CrossRef] 
30. Turmelle, A.S.; Jackson, F.R.; Green, D.; McCracken, G.F.; Rupprecht, C.E. Host immunity to repeated rabies virus infection in big brown bats. J. Gen. Virol. 2010, 91, 2360-2366. [CrossRef]

31. Jackson, F.R.; Turmelle, A.S.; Farino, D.M.; Franka, R.; McCracken, G.F.; Rupprecht, C.E. Experimental rabies virus infection of big brown bats (Eptesicus fuscus). J. Wildl. Dis. 2008, 44, 612-621. [CrossRef]

32. Gnanadurai, C.W.; Zhou, M.; He, W.; Leyson, C.M.; Huang, C.-T.; Salyards, G.; Harvey, S.B.; Chen, Z.; He, B.; Yang, Y.; et al. Presence of virus neutralizing antibodies in cerebral spinal fluid correlates with non-lethal rabies in dogs. PLoS Negl. Trop. Dis. 2013, 7, e2375. [CrossRef]

33. Manickama, R.; Basheer, M.D.; Jayakumar, R. Post-exposure prophylaxis (PEP) of rabies-infected Indian street dogs. Vaccine 2008, 26, 6564-6568. [CrossRef] [PubMed]

34. Rocha, S.M.; de Oliveira, S.V.; Heinemann, M.B.; Gonçalves, V.S.P. Epidemiological Profile of Wild Rabies in Brazil (2002-2012). Transbound. Emerg. Dis. 2017, 64, 624-633. [CrossRef] [PubMed]

35. Kotait, I.; Oliveira, R.d.N.; Carrieri, M.L.; Castilho, J.G.; Macedo, C.I.; Pereira, P.M.C.; Boere, V.; Montebello, L.; Rupprecht, C.E. Non-human primates as a reservoir for rabies virus in Brazil. Zoonoses Public Health 2019, 66, 47-59. [CrossRef] [PubMed]

36. Machado, G.P.; de Paula Antunes, J.M.A.; Uieda, W.; Biondo, A.W.; de Andrade Cruvinel, T.M.; Kataoka, A.P.; Martorelli, L.F.A.; de Jong, D.; Amaral, J.M.G.; Hoppe, E.G.L.; et al. Exposure to rabies virus in a population of free-ranging capuchin monkeys (Cebus apella nigritus) in a fragmented, environmentally protected area in southeastern Brazil. Primates 2012, 53, $227-231$. [CrossRef] [PubMed]

37. WHO. Weekly Epidemiological Record, 2018, vol. 93, 16 [full issue]. Wkly. Epidemiol. Rec. 2018, 93, 201-220.

38. O'Brien, K.L.; Nolan, T. The WHO position on rabies immunization-2018 updates. Vaccine 2019, 37, A85-A87. [CrossRef] [PubMed]

39. Willoughby, R.E.J.; Tieves, K.S.; Hoffman, G.M.; Ghanayem, N.S.; Amlie-Lefond, C.M.; Schwabe, M.J.; Chusid, M.J.; Rupprecht, C.E. Survival after treatment of rabies with induction of coma. N. Engl. J. Med. 2005, 352, 2508-2514. [CrossRef]

40. Zeiler, F.A.; Jackson, A.C. Critical Appraisal of the Milwaukee Protocol for Rabies: This Failed Approach Should Be Abandoned. Can. J. Neurol. Sci. J. Can. Sci. Neurol. 2016, 43, 44-51. [CrossRef]

41. Whitley, R.; Kimberlin, D.W. Herpes simplex: Encephalitis children and adolescents. Semin. Pediatr. Infect. Dis. 2005, 16, 17-23. [CrossRef]

42. Price, R.; Chernik, N.L.; Horta-Barbosa, L.; Posner, J.B. Herpes simplex encephalitis in an anergic patient. Am. J. Med. 1973, 54, 222-228. [CrossRef]

43. Whitley, R.; Lakeman, A.D.; Nahmias, A.; Roizman, B. DNA Restriction-Enzyme Analysis of Herpes Simplex Virus Isolates Obtained from Patients with Encephalitis. N. Engl. J. Med. 1982, 307, 1060-1062. [CrossRef] [PubMed]

44. Gnann, J.; Whitley, R. Herpes Simplex Encephalitis: An Update. Curr. Infect. Dis. Rep. 2017, 19, 13. [CrossRef] [PubMed]

45. Leonard, J.R.; Moran, C.J.; Cross, D.W.T.; Wippold, F.J.; Schlesinger, Y.; Storch, G.A. MR imaging of herpes simplex type I encephalitis in infants and young children: A separate pattern of findings. Am. J. Roentgenol. 2000, 174, 1651-1655. [CrossRef] [PubMed]

46. Vossough, A.; Zimmerman, R.A.; Bilaniuk, L.T.; Schwartz, E.M. Imaging findings of neonatal herpes simplex virus type 2 encephalitis. Neuroradiology 2008, 50, 355-366. [CrossRef]

47. Baskin, H.J.; Hedlund, G. Neuroimaging of herpesvirus infections in children. Pediatr. Radiol. 2007, 37, 949-963. [CrossRef] [PubMed]

48. Bradshaw, M.J.; Venkatesan, A. Herpes Simplex Virus-1 Encephalitis in Adults: Pathophysiology, Diagnosis, and Management. Neurotherapeutics 2016, 13, 493-508. [CrossRef]

49. Steiner, I.; Benninger, F. Manifestations of Herpes Virus Infections in the Nervous System. Neurol. Clin. 2018, 36, 725-738. [CrossRef]

50. Whitley, R.J.; Gnann, J.W. Viral encephalitis: Familiar infections and emerging pathogens. Lancet 2002, 359, 507-513. [CrossRef]

51. Stahl, J.P.; Mailles, A.; De Broucker, T. Herpes simplex encephalitis and management of acyclovir in encephalitis patients in France. Epidemiol. Infect. 2012, 140, 372-381. [CrossRef]

52. Stahl, J.P.; Mailles, A. Herpes simplex virus encephalitis update. Curr. Opin. Infect. Dis. 2019, 32, 239-243. [CrossRef]

53. Etessami, R.; Conzelmann, K.-K.; Fadai-Ghotbi, B.; Natelson, B.; Tsiang, H.; Ceccaldi, P.-E. Spread and pathogenic characteristics of a G-deficient rabies virus recombinant: An in vitro and in vivo study. J. Gen. Virol. 2000, 81, 2147-2153. [CrossRef] [PubMed]

54. Le Blanc, I.; Luyet, P.-P.; Pons, V.; Ferguson, C.; Emans, N.; Petiot, A.; Mayran, N.; Demaurex, N.; Fauré, J.; Sadoul, R.; et al Endosome-to-cytosol transport of viral nucleocapsids. Nat. Cell Biol. 2005, 7, 653-664. [CrossRef] [PubMed]

55. Piccinotti, S.; Kirchhausen, T.; Whelan, S.P.J. Uptake of Rabies Virus into Epithelial Cells by Clathrin-Mediated Endocytosis Depends upon Actin. J. Virol. 2013, 87, 11637-11647. [CrossRef] [PubMed]

56. Lafon, M. Rabies virus receptors. J. Neurovirol. 2005, 11, 82-87. [CrossRef]

57. Baquero, E.; Albertini, A.A.V.; Gaudin, Y. Recent mechanistic and structural insights on class III viral fusion glycoproteins. Curr. Opin. Struct. Biol. 2015, 33, 52-60. [CrossRef]

58. Gaudin, Y.; Tuffereau, C.; Segretain, D.; Knossow, M.; Flamand, A. Reversible conformational changes and fusion activity of rabies virus glycoprotein. J. Virol. 1991, 65, 4853-4859. [CrossRef]

59. Bauer, A.; Nolden, T.; Schröter, J.; Römer-Oberdörfer, A.; Gluska, S.; Perlson, E.; Finke, S. Anterograde glycoprotein-dependent transport of newly generated rabies virus in dorsal root ganglion neurons. J. Virol. 2014, 88, 14172-14183. [CrossRef] 
60. Gluska, S.; Zahavi, E.E.; Chein, M.; Gradus, T.; Bauer, A.; Finke, S.; Perlson, E. Rabies Virus Hijacks and Accelerates the p75NTR Retrograde Axonal Transport Machinery. PLoS Pathog. 2014, 10, e1004348. [CrossRef]

61. Klingen, Y.; Conzelmann, K.-K.; Finke, S. Double-Labeled Rabies Virus: Live Tracking of Enveloped Virus Transport. J. Virol. 2008, 82, 237-245. [CrossRef]

62. Raux, H.; Flamand, A.; Blondel, D. Interaction of the Rabies Virus P Protein with the LC8 Dynein Light Chain. J. Virol. 2000, 74, 10212-10216. [CrossRef]

63. Jacob, Y.; Badrane, H.; Ceccaldi, P.E.; Tordo, N. Cytoplasmic dynein LC8 interacts with lyssavirus phosphoprotein. J. Virol. 2000, 74, 10217-10222. [CrossRef]

64. Mebatsion, T. Extensive attenuation of rabies virus by simultaneously modifying the dynein light chain binding site in the $\mathrm{P}$ protein and replacing Arg333 in the G protein. J. Virol. 2001, 75, 11496-11502. [CrossRef]

65. Bauer, A.; Nolden, T.; Nemitz, S.; Perlson, E.; Finke, S. A Dynein Light Chain 1 Binding Motif in Rabies Virus Polymerase L Protein Plays a Role in Microtubule Reorganization and Viral Primary Transcription. J. Virol. 2015, 89, 9591-9600. [CrossRef] [PubMed]

66. Liu, P.; Yang, J.; Wu, X.; Fu, Z.F. Interactions amongst rabies virus nucleoprotein, phosphoprotein and genomic RNA in virus-infected and transfected cells. J. Gen. Virol. 2004, 85, 3725-3734. [CrossRef]

67. Finke, S.; Mueller-Waldeck, R.; Conzelmann, K.K. Rabies virus matrix protein regulates the balance of virus transcription and replication. J. Gen. Virol. 2003, 84, 1613-1621. [CrossRef]

68. Abraham, G.; Banerjee, A.K. Sequential transcription of the genes of vesicular stomatitis virus. Proc. Natl. Acad. Sci. USA 1976, 73, 1504-1508. [CrossRef] [PubMed]

69. Okumura, A.; Harty, R.N. Rabies virus assembly and budding. Adv. Virus Res. 2011, 79, 23-32. [CrossRef] [PubMed]

70. Mebatsion, T.; Konig, M.; Conzelmann, K.K. Budding of rabies virus particles in the absence of the spike glycoprotein. Cell 1996, 84, 941-951. [CrossRef]

71. Mebatsion, T.; Weiland, F.; Conzelmann, K.K. Matrix protein of rabies virus is responsible for the assembly and budding of bullet-shaped particles and interacts with the transmembrane spike glycoprotein G. J. Virol. 1999, 73, 242-250. [CrossRef]

72. Jackson, A.C.; Ye, H.; Phelan, C.C.; Ridaura-Sanz, C.; Zheng, Q.; Li, Z.; Wan, X.; Lopez-Corella, E. Extraneural organ involvement in human rabies. Lab. Investig. 1999, 79, 945-951.

73. Jogai, S.; Radotra, B.D.; Banerjee, A.K. Rabies viral antigen in extracranial organs: A post-mortem study. Neuropathol. Appl. Neurobiol. 2002, 28, 334-338. [CrossRef]

74. Huffmaster, N.J.; Sollars, P.J.; Richards, A.L.; Pickard, G.E.; Smith, G.A. Dynamic ubiquitination drives herpesvirus neuroinvasion Proc. Natl. Acad. Sci. USA 2015, 112, 12818-12823. [CrossRef]

75. Lee, J.I.; Sollars, P.J.; Baver, S.B.; Pickard, G.E.; Leelawong, M.; Smith, G.A. A herpesvirus encoded deubiquitinase is a novel neuroinvasive determinant. PLoS Pathog. 2009, 5, e1000387. [CrossRef]

76. Aggarwal, A.; Miranda-Saksena, M.; Boadle, R.A.; Kelly, B.J.; Diefenbach, R.J.; Alam, W.; Cunningham, A.L. Ultrastructural Visualization of Individual Tegument Protein Dissociation during Entry of Herpes Simplex Virus 1 into Human and Rat Dorsal Root Ganglion Neurons. J. Virol. 2012, 86, 6123-6137. [CrossRef] [PubMed]

77. Luxton, G.W.; Haverlock, S.; Coller, K.E.; Antinone, S.E.; Pincetic, A.; Smith, G.A. Targeting of herpesvirus capsid transport in axons is coupled to association with specific sets of tegument proteins. Proc. Natl. Acad. Sci. USA 2005, 102, 5832-5837. [CrossRef] [PubMed]

78. Piccinotti, S.; Whelan, S.P.J. Rabies Internalizes into Primary Peripheral Neurons via Clathrin Coated Pits and Requires Fusion at the Cell Body. PLOS Pathog. 2016, 12, e1005753. [CrossRef]

79. Antinone, S.E.; Smith, G.A. Retrograde axon transport of herpes simplex virus and pseudorabies virus: A live-cell comparative analysis. J. Virol. 2010, 84, 1504-1512. [CrossRef]

80. Twelvetrees, A.E.; Pernigo, S.; Sanger, A.; Guedes-Dias, P.; Schiavo, G.; Steiner, R.A.; Dodding, M.P.; Holzbaur, E.L. The Dynamic Localization of Cytoplasmic Dynein in Neurons Is Driven by Kinesin-1. Neuron 2016, 90, 1000-1015. [CrossRef]

81. Wolfstein, A.; Nagel, C.H.; Radtke, K.; Dohner, K.; Allan, V.J.; Sodeik, B. The inner tegument promotes herpes simplex virus capsid motility along microtubules in vitro. Traffic 2006, 7, 227-237. [CrossRef] [PubMed]

82. Koyuncu, O.O.; MacGibeny, M.A.; Enquist, L.W. Latent versus productive infection: The alpha herpesvirus switch. Future Virol. 2018, 13, 431-443. [CrossRef]

83. Nicoll, M.P.; Proenca, J.T.; Efstathiou, S. The molecular basis of herpes simplex virus latency. FEMS Microbiol. Rev. 2012, 36, 684-705. [CrossRef]

84. Philips, T.; Rothstein, J.D. Oligodendroglia: Metabolic supporters of neurons. J. Clin. Investig. 2017, 127, 3271-3280. [CrossRef] [PubMed]

85. Kuhn, S.; Gritti, L.; Crooks, D.; Dombrowski, Y. Oligodendrocytes in Development, Myelin Generation and Beyond. Cells 2019, 8, 1424. [CrossRef] [PubMed]

86. George, D.; Ahrens, P.; Lambert, S. Satellite glial cells represent a population of developmentally arrested Schwann cells. Glia 2018, 66, 1496-1506. [CrossRef] [PubMed]

87. Rajasekhar, P.; Poole, D.P.; Veldhuis, N.A. Chapter Four-Role of Nonneuronal TRPV4 Signaling in Inflammatory Processes. In Advances in Pharmacology; Geraghty, D.P., Rash, L.D., Eds.; Academic Press: Cambridge, MA, USA, 2017; Volume 79, pp. 117-139. ISBN 1054-3589. 
88. Soung, A.; Klein, R.S. Viral Encephalitis and Neurologic Diseases: Focus on Astrocytes. Trends Mol. Med. $2018,24,950-962$. [CrossRef] [PubMed]

89. Ginhoux, F.; Greter, M.; Leboeuf, M.; Nandi, S.; See, P.; Gokhan, S.; Mehler, M.F.; Conway, S.J.; Ng, L.G.; Stanley, E.R.; et al. Fate mapping analysis reveals that adult microglia derive from primitive macrophages. Science 2010, 330, 841-845. [CrossRef]

90. Chen, Z.; Zhong, D.; Li, G. The role of microglia in viral encephalitis: A review. J. Neuroinflamm. 2019, 16, 76. [CrossRef]

91. Metchnikoff, E.; Mesnil, F.; Weinberg, M. Etudes biologiques sur la vieillesse: II. Recherches sur la vieillesse des perroquets. Ann. Inst. Pasteur 1902, 16, 912-917.

92. Carty, M.; Reinert, L.; Paludan, S.R.; Bowie, A.G. Innate antiviral signalling in the central nervous system. Trends Immunol. 2014, 35, 79-87. [CrossRef]

93. Broderick, C.; Hoek, R.M.; Forrester, J.V.; Liversidge, J.; Sedgwick, J.D.; Dick, A.D. Constitutive retinal CD200 expression regulates resident microglia and activation state of inflammatory cells during experimental autoimmune uveoretinitis. Am. J. Pathol. 2002, 161, 1669-1677. [CrossRef]

94. Hoek, R.M.; Ruuls, S.R.; Murphy, C.A.; Wright, G.J.; Goddard, R.; Zurawski, S.M.; Blom, B.; Homola, M.E.; Streit, W.J.; Brown, M.H.; et al. Down-regulation of the macrophage lineage through interaction with OX2 (CD200). Science 2000, 290, 1768-1771. [CrossRef] [PubMed]

95. Yi, M.H.; Zhang, E.; Kang, J.W.; Shin, Y.N.; Byun, J.Y.; Oh, S.H.; Seo, J.H.; Lee, Y.H.; Kim, D.W. Expression of CD200 in alternative activation of microglia following an excitotoxic lesion in the mouse hippocampus. Brain Res. 2012, 1481, 90-96. [CrossRef]

96. Zhang, S.; Wang, X.J.; Tian, L.P.; Pan, J.; Lu, G.Q.; Zhang, Y.J.; Ding, J.Q.; Chen, S. Di CD200-CD200R dysfunction exacerbates microglial activation and dopaminergic neurodegeneration in a rat model of Parkinson's disease. J. Neuroinflamm. 2011, 8, 154. [CrossRef]

97. Burmeister, A.R.; Marriott, I. The Interleukin-10 Family of Cytokines and Their Role in the CNS. Front. Cell. Neurosci. 2018, 12, 458. [CrossRef] [PubMed]

98. Szelényi, J. Cytokines and the central nervous system. Brain Res. Bull. 2001, 54, 329-338. [CrossRef]

99. Almolda, B.; González, B.; Castellano, B. Activated microglial cells acquire an immature dendritic cell phenotype and may terminate the immune response in an acute model of EAE. J. Neuroimmunol. 2010, 223, 39-54. [CrossRef] [PubMed]

100. Almolda, B.; Gonzalez, B.; Castellano, B. Antigen presentation in EAE: Role of microglia, macrophages and dendritic cells. Front. Biosci. (Landmark Ed.) 2011, 16, 1157-1171. [CrossRef]

101. Griffin, D.E. Immune responses to RNA-virus infections of the CNS. Nat. Rev. Immunol. 2003, 3, 493-502. [CrossRef]

102. Malone, K.E.; Stohlman, S.A.; Ramakrishna, C.; Macklin, W.; Bergmann, C.C. Induction of class I antigen processing components in oligodendroglia and microglia during viral encephalomyelitis. Glia 2008, 56, 426-435. [CrossRef]

103. Hamo, L.; Stohlman, S.A.; Otto-Duessel, M.; Bergmann, C.C. Distinct regulation of MHC molecule expression on astrocytes and microglia during viral encephalomyelitis. Glia 2007, 55, 1169-1177. [CrossRef]

104. Frank, E.; Pulver, M.; de Tribolet, N. Expression of class II major histocompatibility antigens on reactive astrocytes and endothelial cells within the gliosis surrounding metastases and abscesses. J. Neuroimmunol. 1986, 12, 29-36. [CrossRef]

105. Rostami, J.; Fotaki, G.; Sirois, J.; Mzezewa, R.; Bergström, J.; Essand, M.; Healy, L.; Erlandsson, A. Astrocytes have the capacity to act as antigen-presenting cells in the Parkinson's disease brain. J. Neuroinflamm. 2020, 17, 119. [CrossRef]

106. Sriram, S. Role of glial cells in innate immunity and their role in CNS demyelination. J. Neuroimmunol. 2011, 239, 13-20. [CrossRef]

107. Appolinário, C.M.; Allendorf, S.D.; Peres, M.G.; Ribeiro, B.D.; Fonseca, C.R.; Vicente, A.F.; De Paula Antunes, J.M.A.; Jane, M. Profile of cytokines and chemokines triggered by wild-type strains of rabies virus in mice. Am. J. Trop. Med. Hyg. 2016, 94, 378-383. [CrossRef]

108. Reinert, L.S.; Lopušná, K.; Winther, H.; Sun, C.; Thomsen, M.K.; Nandakumar, R.; Mogensen, T.H.; Meyer, M.; Vægter, C.; Nyengaard, J.R.; et al. Sensing of HSV-1 by the cGAS-STING pathway in microglia orchestrates antiviral defence in the CNS. Nat. Commun. 2016, 7. [CrossRef]

109. Pfefferkorn, C.; Kallfass, C.; Lienenklaus, S.; Spanier, J.; Kalinke, U.; Rieder, M.; Conzelmann, K.-K.; Michiels, T.; Staeheli, P. Abortively Infected Astrocytes Appear To Represent the Main Source of Interferon Beta in the Virus-Infected Brain. J. Virol. 2016, 90, 2031-2038. [CrossRef]

110. Detje, C.N.; Lienenklaus, S.; Chhatbar, C.; Spanier, J.; Prajeeth, C.K.; Soldner, C.; Tovey, M.G.; Schlüter, D.; Weiss, S.; Stangel, M.; et al. Upon intranasal vesicular stomatitis virus infection, astrocytes in the olfactory bulb are important interferon Beta producers that protect from lethal encephalitis. J. Virol. 2015, 89, 2731-2738. [CrossRef] [PubMed]

111. Kallfass, C.; Ackerman, A.; Lienenklaus, S.; Weiss, S.; Heimrich, B.; Staeheli, P. Visualizing production of beta interferon by astrocytes and microglia in brain of La Crosse virus-infected mice. J. Virol. 2012, 86, 11223-11230. [CrossRef] [PubMed]

112. Adle-Biassette, H.; Bourhy, H.; Gisselbrecht, M.; Chrétien, F.; Wingertsmann, L.; Baudrimont, M.; Rotivel, Y.; Godeau, B.; Gray, F. Rabies encephalitis in a patient with AIDS: A clinicopathological study. Acta Neuropathol. 1996, 92, 415-420. [CrossRef] [PubMed]

113. Miao, F.-M.; Zhang, S.-F.; Wang, S.-C.; Liu, Y.; Zhang, F.; Hu, R.-L. Comparison of immune responses to attenuated rabies virus and street virus in mouse brain. Arch. Virol. 2017, 162, 247-257. [CrossRef]

114. Gnanadurai, C.W.; Yang, Y.; Huang, Y.; Li, Z.; Leyson, C.M.; Cooper, T.L.; Platt, S.R.; Harvey, S.B.; Hooper, D.C.; Faber, M.; et al. Differential host immune responses after infection with wild-type or lab-attenuated rabies viruses in dogs. PLoS Negl. Trop. Dis. 2015, 9, e0004023. [CrossRef] 
115. Brzózka, K.; Finke, S.; Brzo, K. Identification of the Rabies Virus Alpha/Beta Interferon Antagonist: Phosphoprotein P Interferes with Phosphorylation of Interferon Regulatory Factor 3 Identification of the Rabies Virus Alpha/Beta Interferon Antagonist: Phosphoprotein P Interferes. J. Virol. 2005, 79, 7673-7681. [CrossRef]

116. Prehaud, C.; Lay, S.; Dietzschold, B.; Lafon, M. Glycoprotein of nonpathogenic rabies viruses is a key determinant of human cell apoptosis. J. Virol. 2003, 77, 10537-10547. [CrossRef] [PubMed]

117. Baloul, L.; Lafon, M. Apoptosis and rabies virus neuroinvasion. Biochimie 2003, 85, 777-788. [CrossRef]

118. Steiner, I.; Kennedy, P.G.; Pachner, A.R. The neurotropic herpes viruses: Herpes simplex and varicella-zoster. Lancet Neurol. 2007, 6, 1015-1028. [CrossRef]

119. Ito, N.; Moseley, G.W.; Sugiyama, M. The importance of immune evasion in the pathogenesis of rabies virus. Vet. Med. Sci. 2016, 7, 1089-1098. [CrossRef]

120. Dietzschold, B.; Li, J.; Faber, M.; Schnell, M. Concepts in the pathogenesis of rabies. Future Virol. 2008, 3, 481-490. [CrossRef]

121. Iwasaki, Y.; Clark, H.F. Cell to cell transmission of virus in the central nervous system. II. Experimental rabies in mouse. Lab. Investig. 1975, 33, 391-399.

122. Potratz, M.; Zaeck, L.; Christen, M.; Kamp, V.; Klein, A.; Freuling, C.M.; Müller, T.; Finke, S. Astrocyte Infection during Rabies Encephalitis Depends on the Virus Strain and Infection Route as Demonstrated by Novel Quantitative 3D Analysis of Cell Tropism. Cells 2020, 9, 412. [CrossRef]

123. Potratz, M.; Zaeck, L.M.; Weigel, C.; Klein, A.; Freuling, C.M.; Müller, T.; Finke, S. Neuroglia infection by rabies virus after anterograde virus spread in peripheral neurons. Acta Neuropathol. Commun. 2020, 8, 199. [CrossRef]

124. Sung, J.H.; Hayano, M.; Mastri, A.R.; Okagaki, T. A case of human rabies and ultrastructure of the Negri body. J. Neuropathol. Exp. Neurol. 1976, 35, 541-559. [CrossRef] [PubMed]

125. Jackson, A.C.; Phelan, C.C.; Rossiter, J.P. Infection of Bergmann glia in the cerebellum of a skunk experimentally infected with street rabies virus. Can. J. Vet. Res. 2000, 64, 226-228. [PubMed]

126. Prosniak, M.; Zborek, A.; Scott, G.S.; Roy, A.; Phares, T.W.; Koprowski, H.; Hooper, D.C. Differential expression of growth factors at the cellular level in virus-infected brain. Proc. Natl. Acad. Sci. USA 2003, 100, 6765-6770. [CrossRef] [PubMed]

127. Ray, N.B.; Power, C.; Lynch, W.P.P.; Ewalt, L.C.C.; Lodmell, D.L.L. Rabies viruses infect primary cultures of murine, feline, and human microglia and astrocytes. Arch. Virol. 1997, 142, 1011-1019. [CrossRef]

128. Sugamata, M.; Miyazawa, M.; Mori, S.; Spangrude, G.J.; Ewalt, L.C.; Lodmell, D.L. Paralysis of street rabies virus-infected mice is dependent on T lymphocytes. J. Virol. 1992, 66, 1252-1260. [CrossRef]

129. Lafon, M. Immune evasion, a critical strategy for rabies virus. Dev. Biol. 2008, 131, 413-419.

130. Thoulouze, M.I.; Lafage, M.; Schachner, M.; Hartmann, U.; Cremer, H.; Lafon, M. The neural cell adhesion molecule is a receptor for rabies virus. J. Virol. 1998, 72, 7181-7190. [CrossRef]

131. Tuffereau, C.; Bénéjean, J.; Blondel, D.; Kieffer, B.; Flamand, A. Low-affinity nerve-growth factor receptor (P75NTR) can serve as a receptor for rabies virus. EMBO J. 1998, 17, 7250-7259. [CrossRef]

132. Wang, J.; Wang, Z.; Liu, R.; Shuai, L.; Wang, X.; Luo, J.; Wang, C.; Chen, W.; Wang, X.; Ge, J.; et al. Metabotropic glutamate receptor subtype 2 is a cellular receptor for rabies virus. PLoS Pathog. 2018, 2, e1007189. [CrossRef]

133. Lentz, T.L.; Burrage, T.G.; Smith, A.L.; Crick, J.; Tignor, G.H. Is the acetylcholine receptor a rabies virus receptor? Science 1982, 215, 182-184. [CrossRef]

134. Zhang, Y.; Chen, K.; Sloan, S.A.; Bennett, M.L.; Scholze, A.R.; O'Keeffe, S.; Phatnani, H.P.; Guarnieri, P.; Caneda, C.; Ruderisch, N.; et al. An RNA-sequencing transcriptome and splicing database of glia, neurons, and vascular cells of the cerebral cortex. J. Neurosci. 2014, 34, 11929-11947. [CrossRef] [PubMed]

135. Zhang, Y.; Sloan, S.A.A.; Clarke, L.E.E.; Caneda, C.; Plaza, C.A.A.; Blumenthal, P.D.D.; Vogel, H.; Steinberg, G.K.K.; Edwards, M.S.B.S.B.; Li, G.; et al. Purification and Characterization of Progenitor and Mature Human Astrocytes Reveals Transcriptional and Functional Differences with Mouse. Neuron 2016, 89, 37-53. [CrossRef] [PubMed]

136. Hawrylycz, M.J.; Lein, E.S.; Guillozet-Bongaarts, A.L.; Shen, E.H.; Ng, L.; Miller, J.A.; van de Lagemaat, L.N.; Smith, K.A.; Ebbert, A.; Riley, Z.L.; et al. An anatomically comprehensive atlas of the adult human brain transcriptome. Nature 2012, 489, 391-399. [CrossRef]

137. Campadelli-Fiume, G.; Cocchi, F.; Menotti, L.; Lopez, M. The novel receptors that mediate the entry of herpes simplex viruses and animal alphaherpesviruses into cells. Rev. Med. Virol 2000, 10, 305-319. [CrossRef]

138. Takahashi, K.; Nakanishi, H.; Miyahara, M.; Mandai, K.; Satoh, K.; Satoh, A.; Nishioka, H.; Aoki, J.; Nomoto, A.; Mizoguchi, A.; et al. Nectin/PRR: An immunoglobulin-like cell adhesion molecule recruited to cadherin-based adherens junctions through interaction with Afadin, a PDZ domain-containing protein. J. Cell Biol. 1999, 145, 539-549. [CrossRef]

139. Kopp, S.J.; Banisadr, G.; Glajch, K.; Maurer, U.E.; Grunewald, K.; Miller, R.J.; Osten, P.; Spear, P.G. Infection of neurons and encephalitis after intracranial inoculation of herpes simplex virus requires the entry receptor nectin-1. Proc. Natl. Acad. Sci. USA 2009, 106, 17916-17920. [CrossRef]

140. Steinberg, M.W.; Cheung, T.C.; Ware, C.F. The signaling networks of the herpesvirus entry mediator (TNFRSF14) in immune regulation. Immunol. Rev. 2011, 244, 169-187. [CrossRef] [PubMed]

141. Tiwari, V.; Clement, C.; Scanlan, P.M.; Kowlessur, D.; Yue, B.Y.; Shukla, D. A role for herpesvirus entry mediator as the receptor for herpes simplex virus 1 entry into primary human trabecular meshwork cells. J. Virol. 2005, 79, 13173-13179. [CrossRef] 
142. Guzman, G.; Oh, S.; Shukla, D.; Engelhard, H.H.; Valyi-Nagy, T. Expression of entry receptor nectin-1 of herpes simplex virus 1 and/or herpes simplex virus 2 in normal and neoplastic human nervous system tissues. Acta Virol. 2006, 50, 59-66.

143. Haarr, L.; Shukla, D.; Rodahl, E.; Dal Canto, M.C.; Spear, P.G. Transcription from the gene encoding the herpesvirus entry receptor nectin-1 (HveC) in nervous tissue of adult mouse. Virology 2001, 287, 301-309. [CrossRef]

144. Tian, B.; Zhou, M.; Yang, Y.; Yu, L.; Luo, Z.; Tian, D.; Wang, K.; Cui, M.; Chen, H.; Fu, Z.F.; et al. Lab-attenuated rabies virus causes abortive infection and induces cytokine expression in astrocytes by activating mitochondrial antiviral-signaling protein signaling pathway. Front. Immunol. 2018, 8, 2011. [CrossRef]

145. Balachandran, A.; Charlton, K. Experimental rabies infection of non-nervous tissues in skunks (Mephitis mephitis) and foxes (Vulpes vulpes). Vet. Pathol. 1994, 31, 93-102. [CrossRef]

146. Charlton, K.M.; Nadin-Davis, S.; Casey, G.A.; Wandeler, A.I. The long incubation period in rabies: Delayed progression of infection in muscle at the site of exposure. Acta Neuropathol. 1997, 94, 73-77. [CrossRef]

147. Charlton, K.M.; Casey, G.A. Experimental rabies in skunks: Immunofluorescence light and electron microscopic studies. Lab. Investig. 1979, 41, 36-44.

148. Tsiang, H.; Koulakoff, A.; Bizzini, B.; Berwald-Netter, Y. Neurotropism of rabies virus. An in vitro study. J. Neuropathol. Exp. Neurol. 1983, 42, 439-452. [CrossRef]

149. Brzózka, K.; Finke, S.; Conzelmann, K.-K. Inhibition of Interferon Signaling by Rabies Virus Phosphoprotein P: ActivationDependent Binding of STAT1 and STAT2. J. Virol. 2006, 80, 2675-2683. [CrossRef] [PubMed]

150. Ito, N.; Moseley, G.W.; Blondel, D.; Shimizu, K.; Rowe, C.L.; Ito, Y.; Masatani, T.; Nakagawa, K.; Jans, D.A.; Sugiyama, M. Role of interferon antagonist activity of rabies virus phosphoprotein in viral pathogenicity. J. Virol. 2010, 84, 6699-6710. [CrossRef] [PubMed]

151. Vidy, A.; Chelbi-Alix, M.; Blondel, D. Rabies Virus P Protein Interacts with STAT1 and Inhibits Interferon Signal Transduction Pathways. J. Virol. 2005, 79, 14411-14420. [CrossRef] [PubMed]

152. Vidy, A.; El Bougrini, J.; Chelbi-Alix, M.K.; Blondel, D. The Nucleocytoplasmic Rabies Virus P Protein Counteracts Interferon Signaling by Inhibiting both Nuclear Accumulation and DNA Binding of STAT1. J. Virol. 2007, 81, 4255-4263. [CrossRef]

153. Rieder, M.; Brzozka, K.; Pfaller, C.K.; Cox, J.H.; Stitz, L.; Conzelmann, K. Genetic Dissection of Interferon-Antagonistic Functions of Rabies Virus Phosphoprotein: Inhibition of Interferon Regulatory Factor 3 Activation Is Important for Pathogenicity. J. Virol. 2011, 85, 842-852. [CrossRef]

154. Moseley, G.W.; Lahaye, X.; Roth, D.M.; Oksayan, S.; Filmer, R.P.; Rowe, C.L.; Blondel, D.; Jans, D.A. Dual modes of rabies P-protein association with microtubules: A novel strategy to suppress the antiviral response. J. Cell Sci. 2009, 122, 3652-3662. [CrossRef]

155. Bertoune, M.; Nickl, B.; Krieger, T.; Wohlers, L.; Bonaterra, G.A.; Dietzschold, B.; Weihe, E.; Bette, M. The phenotype of the RABV glycoprotein determines cellular and global virus load in the brain and is decisive for the pace of the disease. Virology 2017, 511, 82-94. [CrossRef] [PubMed]

156. Sonthonnax, F.; Besson, B.B.; Bonnaud, E.; Jouvion, G.; Merino, D.; Larrous, F.; Bourhy, H. Lyssavirus matrix protein cooperates with phosphoprotein to modulate the Jak-Stat pathway. Sci. Rep. 2019, 9, 12171. [CrossRef]

157. Zhao, P.; Yang, Y.; Feng, H.; Zhao, L.; Qin, J.; Zhang, T.; Wang, H.; Yang, S.; Xia, X. Global gene expression changes in BV2 microglial cell line during rabies virus infection. Infect. Genet. Evol. 2013, 20, 257-269. [CrossRef] [PubMed]

158. Liu, S.Q.; Xie, Y.; Gao, X.; Wang, Q.; Zhu, W.Y. Inflammatory response and MAPK and NF-kB pathway activation induced by natural street rabies virus infection in the brain tissues of dogs and humans. Virol. J. 2020, 17, 157. [CrossRef]

159. Liu, S.Q.; Gao, X.; Xie, Y.; Wang, Q.; Zhu, W.Y. Rabies viruses of different virulence regulates inflammatory responses both in vivo and in vitro via MAPK and NF-kB pathway. Mol. Immunol. 2020, 125, 70-82. [CrossRef]

160. Feige, L.; Kozaki, T.; Dias de Melo, G.; Guillemot, V.; Larrous, F.; Ginhoux, F.; Bourhy, H. Cell-type specific innate immune responses shape rabies virus tropism. Manuscr. Submitt. Publ. 2021. [CrossRef]

161. Valério-Gomes, B.; Guimarães, D.M.; Szczupak, D.; Lent, R. The Absolute Number of Oligodendrocytes in the Adult Mouse Brain. Front. Neuroanat. 2018, 12, 90. [CrossRef]

162. Osanai, Y.; Shimizu, T.; Mori, T.; Yoshimura, Y.; Hatanaka, N.; Nambu, A.; Kimori, Y.; Koyama, S.; Kobayashi, K.; Ikenaka, K. Rabies virus-mediated oligodendrocyte labeling reveals a single oligodendrocyte myelinates axons from distinct brain regions. Glia 2017, 65, 93-105. [CrossRef] [PubMed]

163. Gold, R.; Archelos, J.J.; Hartung, H.P. Mechanisms of immune regulation in the peripheral nervous system. Brain Pathol. 1999, 9 , 343-360. [CrossRef]

164. Ydens, E.; Lornet, G.; Smits, V.; Goethals, S.; Timmerman, V.; Janssens, S. The neuroinflammatory role of Schwann cells in disease. Neurobiol. Dis. 2013, 55, 95-103. [CrossRef]

165. Jenson, A.B.; Rabin, E.R.; Bentinck, D.C.; Melnick, J.L. Rabies virus neuronitis. J. Virol. 1969, 3, 265-269. [CrossRef] [PubMed]

166. Charlton, K.M.; Casey, G.A.; Wandeler, A.I.; Nadin-Davis, S. Early events in rabies virus infection of the central nervous system in skunks (Mephitis mephitis). Acta Neuropathol. 1995, 91, 89-98. [CrossRef] [PubMed]

167. Zaeck, L.; Potratz, M.; Freuling, C.M.; Müller, T.; Finke, S. High-Resolution 3D Imaging of Rabies Virus Infection in Solvent-Cleared Brain Tissue. JoVE 2019, e59402. [CrossRef]

168. Whitley, R.; Baines, J. Clinical management of herpes simplex virus infections: Past, present, and future. F1000Res 2018, 7. [CrossRef] [PubMed] 
169. Obara, Y.; Furuta, Y.; Takasu, T.; Suzuki, S.; Suzuki, H.; Matsukawa, S.; Fujioka, Y.; Takahashi, H.; Kurata, T.; Nagashima, K. Distribution of herpes simplex virus types 1 and 2 genomes in human spinal ganglia studied by PCR and in situ hybridization. J. Med. Virol. 1997, 52, 136-142. [CrossRef]

170. Richter, E.R.; Dias, J.K.; Gilbert, J.E.; Atherton, S.S. Distribution of herpes simplex virus type 1 and varicella zoster virus in ganglia of the human head and neck. J. Infect. Dis. 2009, 200, 1901-1906. [CrossRef] [PubMed]

171. Davis, L.E.; Johnson, R.T. An explanation for the localization of herpes simplex encephalitis? Ann. Neurol. 1979, 5, 2-5. [CrossRef]

172. Johnson, R.T.; Mims, C.A. Pathogenesis of viral infections of the nervous system. N. Engl. J. Med. 1968, 278, 23-30. [CrossRef]

173. Esiri, M.M. Herpes-Simplex Encephalitis—an Immunohistological Study of the Distribution of Viral-Antigen within the Brain. J. Neurol. Sci. 1982, 54, 209-226. [CrossRef]

174. Kennedy, P.G.; Clements, G.B.; Brown, S.M. Differential susceptibility of human neural cell types in culture to infection with herpes simplex virus. Brain 1983, 106 Pt 1, 101-119. [CrossRef]

175. Bansode, Y.D.; Chattopadhyay, D.; Saha, B. Innate immune response in astrocytes infected with herpes simplex virus 1. Arch. Virol. 2019, 164, 1433-1439. [CrossRef]

176. Bansode, Y.D.; Chattopadhyay, D.; Saha, B. Transcriptomic Analysis of Interferon Response in Toll-Like Receptor 2 Ligand-Treated and Herpes Simplex Virus 1-Infected Neurons and Astrocytes. Viral Immunol. 2020. [CrossRef]

177. Liu, Z.; Guan, Y.; Sun, X.; Shi, L.; Liang, R.; Lv, X.; Xin, W. HSV-1 activates NF-kappaB in mouse astrocytes and increases TNF-alpha and IL-6 expression via Toll-like receptor 3. Neurol. Res. 2013, 35, 755-762. [CrossRef]

178. Gumenyuk, A.V.; Tykhomyrov, A.A.; Savosko, S.I.; Guzyk, M.M.; Rybalko, S.L.; Ryzha, A.O.; Chaikovsky, Y.B. State of Astrocytes in the Mice Brain under Conditions of Herpes Viral Infection and Modeled Stroke. Neurophysiology 2018, 50, 326-331. [CrossRef]

179. Hensel, N.; Raker, V.; Forthmann, B.; Detering, N.T.; Kubinski, S.; Buch, A.; Katzilieris-Petras, G.; Spanier, J.; Gudi, V.; Wagenknecht, S.; et al. HSV-1 triggers paracrine fibroblast growth factor response from cortical brain cells via immediate-early protein ICP0. J. Neuroinflamm. 2019, 16, 248. [CrossRef] [PubMed]

180. Fiacco, T.A.; Agulhon, C.; McCarthy, K.D. Sorting Out Astrocyte Physiology from Pharmacology. Annu. Rev. Pharmacol. Toxicol. 2009, 49, 151-174. [CrossRef] [PubMed]

181. Aravalli, R.N.; Hu, S.; Rowen, T.N.; Palmquist, J.M.; Lokensgard, J.R. TLR2-mediated proinflammatory cytokine and chemokine production by microglial cells in response to herpes simplex virus. J. Immunol. 2005, 175, 4189-4193. [CrossRef]

182. Fekete, R.; Cserep, C.; Lenart, N.; Toth, K.; Orsolits, B.; Martinecz, B.; Mehes, E.; Szabo, B.; Nemeth, V.; Gonci, B.; et al. Microglia control the spread of neurotropic virus infection via P2Y12 signalling and recruit monocytes through P2Y12-independent mechanisms. Acta Neuropathol. 2018, 136, 461-482. [CrossRef]

183. Bello-Morales, R.; Fedetz, M.; Alcina, A.; Tabares, E.; Lopez-Guerrero, J.A. High susceptibility of a human oligodendroglial cell line to herpes simplex type 1 infection. J. Neurovirol. 2005, 11, 190-198. [CrossRef]

184. Kastrukoff, L.F.; Kim, S.U. Oligodendrocytes from human donors differ in resistance to herpes simplex virus 1 (HSV-1). Glia 2002, 38, 87-92. [CrossRef]

185. Ugolini, G.; Kuypers, H.G.; Simmons, A. Retrograde transneuronal transfer of herpes simplex virus type 1 (HSV 1) from motoneurones. Brain Res. 1987, 422, 242-256. [CrossRef]

186. Boukhvalova, M.S.; Mortensen, E.; Mbaye, A.; Lopez, D.; Kastrukoff, L.; Blanco, J.C.G. Herpes Simplex Virus 1 Induces Brain Inflammation and Multifocal Demyelination in the Cotton Rat Sigmodon hispidus. J. Virol. 2019, 94. [CrossRef] [PubMed]

187. Townsend, J.J.; Collins, P.K. Peripheral nervous system demyelination with herpes simplex virus. J. Neuropathol. Exp. Neurol. 1986, 45, 419-425. [CrossRef] [PubMed]

188. Shimeld, C.; Efstathiou, S.; Hill, T. Tracking the spread of a lacZ-tagged herpes simplex virus type 1 between the eye and the nervous system of the mouse: Comparison of primary and recurrent infection. J. Virol. 2001, 75, 5252-5262. [CrossRef]

189. Hill, T.J.; Field, H.J. The interaction of herpes simplex virus with cultures of peripheral nervous tissue: An electron microscopic study. J. Gen. Virol. 1973, 21, 123-133. [CrossRef]

190. Wilkinson, R.; Leaver, C.; Simmons, A.; Pereira, R.A. Restricted replication of herpes simplex virus in satellite glial cell cultures clonally derived from adult mice. J. Neurovirol. 1999, 5, 384-391. [CrossRef]

191. Zerboni, L.; Che, X.; Reichelt, M.; Qiao, Y.; Gu, H.; Arvin, A. Herpes simplex virus 1 tropism for human sensory ganglion neurons in the severe combined immunodeficiency mouse model of neuropathogenesis. J. Virol. 2013, 87, 2791-2802. [CrossRef]

192. Suja, M.S.; Mahadevan, A.; Madhusudana, S.N.; Shankar, S.K. Role of Apoptosis in Rabies Viral Encephalitis: A Comparative Study in Mice, Canine, and Human Brain with a Review of Literature. Patholog. Res. Int. 2011, 2011, 1-13. [CrossRef]

193. Lokensgard, J.R.; Hu, S.; Sheng, W.; van Oijen, M.; Cox, D.; Cheeran, M.C.-J.J.; Peterson, P.K.; Lokensgard, J.R.; Hu, S.; Wen, J.R.; et al. Robust expression of TNF-, IL-1, RANTES, and IP-10 by human microglial cells during nonproductive infection with herpes simplex virus. J. Neurovirol. 2001, 7, 208-219. [CrossRef]

194. Rosenberg, G.A. Neurological diseases in relation to the blood-brain barrier. J. Cereb. Blood Flow Metab. 2012, 32, 1139-1151. [CrossRef]

195. Schnell, M.J.; McGettigan, J.P.; Wirblich, C.; Papaneri, A. The cell biology of rabies virus: Using stealth to reach the brain. Nat. Rev. Microbiol. 2009, 8, 51-61. [CrossRef] [PubMed]

196. Pape, K.; Tamouza, R.; Leboyer, M.; Zipp, F. Immunoneuropsychiatry-Novel perspectives on brain disorders. Nat. Rev. Neurol. 2019, 15, 317-328. [CrossRef] [PubMed]

197. Scott, T.; Nel, L. Subversion of the Immune Response by Rabies Virus. Viruses 2016, 8, 231. [CrossRef] [PubMed] 
198. Roy, A.; Hooper, D.C. Lethal Silver-Haired Bat Rabies Virus Infection Can Be Prevented by Opening the Blood-Brain Barrier. J. Virol. 2007, 81, 7993-7998. [CrossRef] [PubMed]

199. Phares, T.W.; Kean, R.B.; Mikheeva, T.; Hooper, D.C. Regional Differences in Blood-Brain Barrier Permeability Changes and Inflammation in the Apathogenic Clearance of Virus from the Central Nervous System. J. Immunol. 2006, 176, 7666-7675. [CrossRef]

200. Roy, A.; Phares, T.W.; Koprowski, H.; Hooper, D.C. Failure to open the blood-brain barrier and deliver immune effectors to central nervous system tissues leads to the lethal outcome of silver-haired bat rabies virus infection. J. Virol. 2007, 81, 1110-1118. [CrossRef]

201. Roy, A.; Hooper, D.C. Immune evasion by rabies viruses through the maintenance of blood-brain barrier integrity. J. Neurovirol. 2008, 14, 401-411. [CrossRef]

202. Hooper, D.C.; Roy, A.; Barkhouse, D.A.; Li, J.; Kean, R.B. Rabies Virus Clearance from the Central Nervous System, 1st ed.; Elsevier Inc.: Amsterdam, The Netherlands, 2011; Volume 79, ISBN 9780123870407.

203. Alvarez, L.; Fajardo, R.; Lopez, E.; Pedroza, R.; Hemachudha, T.; Kamolvarin, N.; Cortes, G.; Baer, G.M. Partial recovery from rabies in a nine-year-old boy. Pediatr. Infect. Dis. J. 1994, 13, 1154-1155. [CrossRef]

204. Hattwick, M.A.; Weis, T.T.; Stechschulte, C.J.; Baer, G.M.; Gregg, M.B. Recovery from rabies. A case report. Ann. Intern. Med. 1972, 76, 931-942. [CrossRef]

205. Porras, C.; Barboza, J.J.; Fuenzalida, E.; Adaros, H.L.; Oviedo, A.M.; Furst, J. Recovery from rabies in man. Ann. Intern. Med. 1976, 85, 44-48. [CrossRef] [PubMed]

206. Madhusudana, S.N.; Nagaraj, D.; Uday, M.; Ratnavalli, E.; Kumar, M.V. Partial recovery from rabies in a six-year-old girl. Int. J. Infect. Dis. IJID Off. Publ. Int. Soc. Infect. Dis. 2002, 6, 85-86. [CrossRef]

207. Hu, W.T.; Willoughby, R.E.J.; Dhonau, H.; Mack, K.J. Long-term follow-up after treatment of rabies by induction of coma. N. Engl. J. Med. 2007, 357, 945-946. [CrossRef] [PubMed]

208. Centers for Disease Control and Prevention (CDC). Recovery of a patient from clinical rabies-Wisconsin, 2004. MMWR. Morb. Mortal. Wkly. Rep. 2004, 53, 1171-1173.

209. Centers for Disease Control and Prevention (CDC). Recovery of a patient from clinical rabies-California, 2011. MMWR. Morb. Mortal. Wkly. Rep. 2012, 61, 61-65.

210. Dietzschold, B.; Kao, M.; Zheng, Y.M.; Chen, Z.Y.; Maul, G.; Fu, Z.F.; Rupprecht, C.E.; Koprowski, H. Delineation of putative mechanisms involved in antibody-mediated clearance of rabies virus from the central nervous system. Proc. Natl. Acad. Sci. USA 1992, 89, 7252-7256. [CrossRef]

211. Rowell, J.F.; Griffin, D.E. The inflammatory response to nonfatal Sindbis virus infection of the nervous system is more severe in SJL than in BALB/c mice and is associated with low levels of IL-4 mRNA and high levels of IL-10-producing CD4+ T cells. J. Immunol. 1999, 162, 1624-1632.

212. Singh, A.K.; Yang, J.-Q.; Parekh, V.V.; Wei, J.; Wang, C.-R.; Joyce, S.; Singh, R.R.; Van Kaer, L. The natural killer T cell ligand alpha-galactosylceramide prevents or promotes pristane-induced lupus in mice. Eur. J. Immunol. 2005, 35, 1143-1154. [CrossRef]

213. Lodmell, D.L.; Ewalt, L.C. Pathogenesis of street rabies virus infections in resistant and susceptible strains of mice. J. Virol. 1985, 55, 788-795. [CrossRef]

214. Wang, H.; Zhang, G.; Wen, Y.; Yang, S.; Xia, X.; Fu, Z.F. Intracerebral Administration of Recombinant Rabies Virus Expressing GM-CSF Prevents the Development of Rabies after Infection with Street Virus. PLoS ONE 2011, 6, e25414. [CrossRef]

215. de Melo, G.D.; Sonthonnax, F.; Lepousez, G.; Jouvion, G.; Minola, A.; Zatta, F.; Larrous, F.; Kergoat, L.; Mazo, C.; Moigneu, C.; et al. A combination of two human monoclonal antibodies cures symptomatic rabies. EMBO Mol. Med. 2020, 12, e12628. [CrossRef] [PubMed]

216. Hellert, J.; Buchrieser, J.; Larrous, F.; Minola, A.; de Melo, G.D.; Soriaga, L.; England, P.; Haouz, A.; Telenti, A.; Schwartz, O.; et al. Structure of the prefusion-locking broadly neutralizing antibody RVC20 bound to the rabies virus glycoprotein. Nat. Commun. 2020, 11, 596. [CrossRef]

217. Liu, H.; Qiu, K.; He, Q.; Lei, Q.; Lu, W. Mechanisms of Blood-Brain Barrier Disruption in Herpes Simplex Encephalitis. J. Neuroimmune Pharmacol. 2019, 14, 157-172. [CrossRef] [PubMed]

218. Lundberg, P.; Ramakrishna, C.; Brown, J.; Tyszka, J.M.; Hamamura, M.; Hinton, D.R.; Kovats, S.; Nalcioglu, O.; Weinberg, K.; Openshaw, H.; et al. The immune response to herpes simplex virus type 1 infection in susceptible mice is a major cause of central nervous system pathology resulting in fatal encephalitis. J. Virol. 2008, 82, 7078-7088. [CrossRef]

219. Mancini, M.; Vidal, S.M. Insights into the pathogenesis of herpes simplex encephalitis from mouse models. Mamm. Genome 2018, 29, 425-445. [CrossRef]

220. Chan, W.L.; Javanovic, T.; Lukic, M.L. Infiltration of immune T cells in the brain of mice with herpes simplex virus-induced encephalitis. J. Neuroimmunol. 1989, 23, 195-201. [CrossRef]

221. Muller, W.A. Leukocyte-endothelial cell interactions in the inflammatory response. Lab. Investig. 2002, 82, 521-533. [CrossRef]

222. Brundula, V.; Rewcastle, N.B.; Metz, L.M.; Bernard, C.C.; Yong, V.W. Targeting leukocyte MMPs and transmigration: Minocycline as a potential therapy for multiple sclerosis. Brain 2002, 125, 1297-1308. [CrossRef]

223. Yong, V.W.; Power, C.; Edwards, D.R. Metalloproteinases in biology and pathology of the nervous system. Nat. Rev. Neurosci. 2001, 2, 502-511. [CrossRef] 
224. Subileau, E.A.; Rezaie, P.; Davies, H.A.; Colyer, F.M.; Greenwood, J.; Male, D.K.; Romero, I.A. Expression of Chemokines and Their Receptors by Human Brain Endothelium: Implications for Multiple Sclerosis. J. Neuropathol. Exp. Neurol. 2009, 68, 227-240. [CrossRef]

225. Kim, Y.C.; Bang, D.; Lee, S.; Lee, K.H. The effect of herpesvirus infection on the expression of cell adhesion molecules on cultured human dermal microvascular endothelial cells. J. Dermatol. Sci. 2000, 24, 38-47. [CrossRef]

226. Sobel, R.A.; Mitchell, M.E.; Fondren, G. Intercellular adhesion molecule-1 (ICAM-1) in cellular immune reactions in the human central nervous system. Am. J. Pathol. 1990, 136, 1309-1316. [PubMed]

227. Brankin, B.; Hart, M.N.; Cosby, S.L.; Fabry, Z.; Allen, I.V. Adhesion molecule expression and lymphocyte adhesion to cerebral endothelium: Effects of measles virus and herpes simplex 1 virus. J. Neuroimmunol. 1995, 56, 1-8. [CrossRef]

228. He, Q.; Liu, H.; Huang, C.; Wang, R.; Luo, M.; Lu, W. Herpes Simplex Virus 1-Induced Blood-Brain Barrier Damage Involves Apoptosis Associated With GM130-Mediated Golgi Stress. Front. Mol. Neurosci. 2020, 13, 2. [CrossRef]

229. Zhou, Y.; Lu, Z.N.; Guo, Y.J.; Mei, Y.W. Favorable effects of MMP-9 knockdown in murine herpes simplex encephalitis using small interfering RNA. Neurol. Res. 2010, 32, 801-809. [CrossRef] [PubMed]

230. Wang, P.; Dai, J.; Bai, F.; Kong, K.F.; Wong, S.J.; Montgomery, R.R.; Madri, J.A.; Fikrig, E. Matrix metalloproteinase 9 facilitates West Nile virus entry into the brain. J. Virol. 2008, 82, 8978-8985. [CrossRef]

231. Hu, S.; Sheng, W.S.; Schachtele, S.J.; Lokensgard, J.R. Reactive oxygen species drive herpes simplex virus (HSV)-1-induced proinflammatory cytokine production by murine microglia. J. Neuroinflamm. 2011, 8, 123. [CrossRef]

232. Roberts, T.K.; Eugenin, E.A.; Lopez, L.; Romero, I.A.; Weksler, B.B.; Couraud, P.O.; Berman, J.W. CCL2 disrupts the adherens junction: Implications for neuroinflammation. Lab. Investig. 2012, 92, 1213-1233. [CrossRef]

233. Stamatovic, S.M.; Keep, R.F.; Kunkel, S.L.; Andjelkovic, A. V Potential role of MCP-1 in endothelial cell tight junction "opening": Signaling via Rho and Rho kinase. J. Cell Sci. 2003, 116, 4615-4628. [CrossRef]

234. Jung, J.S.; Bhat, R.V.; Preston, G.M.; Guggino, W.B.; Baraban, J.M.; Agre, P. Molecular characterization of an aquaporin cDNA from brain: Candidate osmoreceptor and regulator of water balance. Proc. Natl. Acad. Sci. USA 1994, 91, 13052-13056. [CrossRef]

235. Papadopoulos, M.C.; Verkman, A.S. Aquaporin water channels in the nervous system. Nat. Rev. Neurosci. 2013, 14, 265-277. [CrossRef] [PubMed]

236. Safain, M.G.; Roguski, M.; Kryzanski, J.T.; Weller, S.J. A review of the combined medical and surgical management in patients with herpes simplex encephalitis. Clin. Neurol. Neurosurg. 2015, 128, 10-16. [CrossRef] [PubMed]

237. Armien, A.G.; Hu, S.; Little, M.R.; Robinson, N.; Lokensgard, J.R.; Low, W.C.; Cheeran, M.C. Chronic cortical and subcortical pathology with associated neurological deficits ensuing experimental herpes encephalitis. Brain Pathol. 2010, 20, 738-750. [CrossRef]

238. Michinaga, S.; Koyama, Y. Dual Roles of Astrocyte-Derived Factors in Regulation of Blood-Brain Barrier Function after Brain Damage. Int. J. Mol. Sci. 2019, 20, 571. [CrossRef]

239. Takeuchi, O.; Akira, S. Pattern Recognition Receptors and Inflammation. Cell 2010, 140, 805-820. [CrossRef] [PubMed]

240. Christensen, M.H.; Paludan, S.R. Viral evasion of DNA-stimulated innate immune responses. Cell. Mol. Immunol. 2017, 14, 4-13. [CrossRef]

241. Guo, Y.J.; Luo, T.; Wu, F.; Mei, Y.W.; Peng, J.; Liu, H.; Li, H.R.; Zhang, S.L.; Dong, J.H.; Fang, Y.; et al. Involvement of TLR2 and TLR9 in the anti-inflammatory effects of chlorogenic acid in HSV-1-infected microglia. Life Sci. 2015, 127, 12-18. [CrossRef]

242. Zhou, Y.; Ye, L.; Wan, Q.; Zhou, L.; Wang, X.; Li, J.; Hu, S.; Zhou, D.; Ho, W. Activation of Toll-like receptors inhibits herpes simplex virus-1 infection of human neuronal cells. J. Neurosci. Res. 2009, 87, 2916-2925. [CrossRef]

243. Furr, S.R.; Marriott, I. Viral CNS infections: Role of glial pattern recognition receptors in neuroinflammation. Front. Microbiol. 2012, 3, 201. [CrossRef]

244. Kigerl, K.A.; de Rivero Vaccari, J.P.; Dietrich, W.D.; Popovich, P.G.; Keane, R.W. Pattern recognition receptors and central nervous system repair. Exp. Neurol. 2014, 258, 5-16. [CrossRef]

245. Katz, I.S.S.; Guedes, F.; Fernandes, E.R.; dos Ramos Silva, S. Immunological aspects of rabies: A literature review. Arch. Virol. 2017, 162, 3251-3268. [CrossRef]

246. Yordy, B.; Iijima, N.; Huttner, A.; Leib, D.; Iwasaki, A. A neuron-specific role for autophagy in antiviral defense against herpes simplex virus. Cell Host Microbe 2012, 12, 334-345. [CrossRef] [PubMed]

247. Peng, J.; Zhu, S.; Hu, L.; Ye, P.; Wang, Y.; Tian, Q.; Mei, M.; Chen, H.; Guo, X. Wild-type rabies virus induces autophagy in human and mouse neuroblastoma cell lines. Autophagy 2016, 12, 1704-1720. [CrossRef] [PubMed]

248. Yakoub, A.M.; Shukla, D. Autophagy stimulation abrogates herpes simplex virus-1 infection. Sci. Rep. 2015, 5, 9730. [CrossRef]

249. Nakamichi, K.; Saiki, M.; Sawada, M.; Takayama-Ito, M.; Yamamuro, Y.; Morimoto, K.; Kurane, I. Rabies Virus-Induced Activation of Mitogen-Activated Protein Kinase and NF- B Signaling Pathways Regulates Expression of CXC and CC Chemokine Ligands in Microglia. J. Virol. 2005, 79, 11801-11812. [CrossRef] [PubMed]

250. Fujii, S.; Akaike, T.; Maeda, H. Role of nitric oxide in pathogenesis of herpes simplex virus encephalitis in rats. Virology 1999, 256, 203-212. [CrossRef] [PubMed]

251. Cagnin, A.; Myers, R.; Gunn, R.N.; Lawrence, A.D.; Stevens, T.; Kreutzberg, G.W.; Jones, T.; Banati, R.B. In Vivo visualization of activated glia by [11C] (R)-PK11195-PET following herpes encephalitis reveals projected neuronal damage beyond the primary focal lesion. Brain 2001, 124, 2014-2027. [CrossRef] 
252. Reinert, L.S.; Harder, L.; Holm, C.K.; Iversen, M.B.; Horan, K.A.; Dagnæs-Hansen, F.; Ulhøi, B.P.; Holm, T.H.; Mogensen, T.H.; Owens, T.; et al. TLR3 deficiency renders astrocytes permissive to herpes simplex virus infection and facilitates establishment of CNS infection in mice. J. Clin. Investig. 2012, 122, 1368-1376. [CrossRef]

253. Conrady, C.D.; Drevets, D.A.; Carr, D.J. Herpes simplex type I (HSV-1) infection of the nervous system: Is an immune response a good thing? J. Neuroimmunol. 2010, 220, 1-9. [CrossRef]

254. Li, J.; Faber, M.; Dietzschold, B.; Hooper, D.C. The Role of Toll-Like Receptors in the Induction of Immune Responses during Rabies Virus Infection, 1st ed.; Elsevier Inc.: Amsterdam, The Netherlands, 2011; Volume 79, ISBN 9780123870407.

255. Faul, E.J.; Wanjalla, C.N.; Suthar, M.S.; Gale, M.; Wirblich, C.; Schnell, M.J. Rabies Virus Infection Induces Type I Interferon Production in an IPS-1 Dependent Manner While Dendritic Cell Activation Relies on IFNAR Signaling. PLoS Pathog. 2010, 6, e1001016. [CrossRef]

256. Prehaud, C.; Mégret, F.; Lafage, M.; Lafon, M. Virus infection switches TLR-3-positive human neurons to become strong producers of beta interferon. J. Virol. 2005, 79, 12893-12904. [CrossRef] [PubMed]

257. Ménager, P.; Roux, P.; Mégret, F.; Bourgeois, J.-P.; Le Sourd, A.-M.; Danckaert, A.; Lafage, M.; Préhaud, C.; Lafon, M. Toll-like receptor 3 (TLR3) plays a major role in the formation of rabies virus Negri Bodies. PLoS Pathog. 2009, 5, e1000315. [CrossRef] [PubMed]

258. Jackson, A.C.; Rossiter, J.P.; Lafon, M. Expression of Toll-like receptor 3 in the human cerebellar cortex in rabies, herpes simplex encephalitis, and other neurological diseases. J. Neurovirol. 2006, 12, 229-234. [CrossRef]

259. Luo, Z.; Li, Y.; Zhou, M.; Lv, L.; Wu, Q.; Chen, C.; Zhang, Y.; Sui, B.; Tu, C.; Cui, M.; et al. Toll-like receptor 7 enhances rabies virus-induced humoral immunity by facilitating the formation of germinal centers. Front. Immunol. 2019, 10. [CrossRef]

260. Liu, R.; Wang, J.; Yang, Y.; Khan, I.; Zhu, N. Rabies virus lipopeptide conjugated to a TLR7 agonist improves the magnitude and quality of the Th1-biased humoral immune response in mice. Virology 2016, 497, 102-110. [CrossRef]

261. Luo, Z.; Lv, L.; Li, Y.; Sui, B.; Wu, Q.; Zhang, Y.; Pei, J.; Li, M.; Zhou, M.; Hooper, D.C.; et al. Dual Role of Toll-Like Receptor 7 in the Pathogenesis of Rabies Virus in a Mouse Model. J. Virol. 2020, 94. [CrossRef]

262. Mercer, J.; Greber, U.F. Virus interactions with endocytic pathways in macrophages and dendritic cells. Trends Microbiol. 2013, 21, 380-388. [CrossRef] [PubMed]

263. Lytle, A.G.; Shen, S.; McGettigan, J.P. Lymph Node but Not Intradermal Injection Site Macrophages Are Critical for Germinal Center Formation and Antibody Responses to Rabies Vaccination. J. Virol. 2015, 89, 2842-2848. [CrossRef]

264. Hornung, V.; Ellegast, J.; Kim, S.; Brzózka, K.; Jung, A.; Kato, H.; Poeck, H.; Akira, S.; Conzelmann, K.-K.; Schlee, M.; et al. 5'-Triphosphate RNA is the ligand for RIG-I. Science 2006, 314, 994-997. [CrossRef]

265. Yang, Y.; Huang, Y.; Gnanadurai, C.W.; Cao, S.; Liu, X.; Cui, M.; Fu, Z.F. The Inability of Wild-Type Rabies Virus to Activate Dendritic Cells Is Dependent on the Glycoprotein and Correlates with Its Low Level of the De Novo -Synthesized Leader RNA. J. Virol. 2015, 89, 2157-2169. [CrossRef]

266. Lafon, M. Modulation of the immune response in the nervous system by rabies virus. Curr. Top. Microbiol. Immunol. 2005, 289, 239-258. [CrossRef] [PubMed]

267. Sui, B.; Chen, D.; Liu, W.; Tian, B.; Lv, L.; Pei, J.; Wu, Q.; Zhou, M.; Fu, Z.F.; Zhang, Y.; et al. Comparison of lncRNA and mRNA expression in mouse brains infected by a wild-type and a lab-attenuated Rabies lyssavirus. J. Gen. Virol. 2021, 102. [CrossRef]

268. Ménager, P.; Roux, P.; Mégret, F.; Préhaud, C.; Bourgeois, J.-P.; Le Sourd, A.-M.; Lafage, M.; Lafon, M. TLR3 is a key component of rabies virus induced Negri bodies. BMC Proc. 2008, 2, 3. [CrossRef]

269. Matsumoto, M.; Oshiumi, H.; Seya, T. Antiviral responses induced by the TLR3 pathway. Rev. Med. Virol. 2011, 21, 67-77. [CrossRef] [PubMed]

270. Lahaye, X.; Vidy, A.; Pomier, C.; Obiang, L.; Harper, F.; Gaudin, Y.; Blondel, D. Functional Characterization of Negri Bodies (NBs) in Rabies Virus-Infected Cells: Evidence that NBs Are Sites of Viral Transcription and Replication. J. Virol. 2009, 83, 7948-7958. [CrossRef]

271. Nikolic, J.; Le Bars, R.; Lama, Z.; Scrima, N.; Lagaudrière-Gesbert, C.; Gaudin, Y.; Blondel, D. Negri bodies are viral factories with properties of liquid organelles. Nat. Commun. 2017, 8. [CrossRef]

272. Salaun, B.; Coste, I.; Rissoan, M.-C.; Lebecque, S.J.; Renno, T. TLR3 Can Directly Trigger Apoptosis in Human Cancer Cells. J. Immunol. 2006, 176, 4894-4901. [CrossRef]

273. Plioplys, A.V.; Massimini, N. Alpha/Beta Interferon Is a Neuronal Growth Factor. Neuroimmunomodulation 1995, 2, 31-35. [CrossRef]

274. Meucci, O.; Fatatis, A.; Simen, A.A.; Bushell, T.J.; Gray, P.W.; Miller, R.J. Chemokines regulate hippocampal neuronal signaling and gp120 neurotoxicity. Proc. Natl. Acad. Sci. USA 1998, 95, 14500-14505. [CrossRef]

275. Pizzi, M.; Sarnico, I.; Boroni, F.; Benarese, M.; Dreano, M.; Garotta, G.; Valerio, A.; Spano, P. Prevention of neuron and oligodendrocyte degeneration by interleukin-6 (IL-6) and IL-6 receptor/IL-6 fusion protein in organotypic hippocampal slices. Mol. Cell. Neurosci. 2004, 25, 301-311. [CrossRef]

276. Hirota, H.; Kiyama, H.; Kishimoto, T.; Taga, T. Accelerated nerve regeneration in mice by upregulated expression of interleukin (IL) 6 and IL-6 receptor after trauma. J. Exp. Med. 1996, 183, 2627-2634. [CrossRef] [PubMed]

277. Iwasaki, Y.; Tobita, M. Pathology. In Rabies; Jackson, A.C., Fooks, A.R., Eds.; Elsevier: San Diego, CA, USA, 2002 ; pp. $283-306$.

278. Kassis, R.; Larrous, F.; Estaquier, J.; Bourhy, H. Lyssavirus Matrix Protein Induces Apoptosis by a TRAIL-Dependent Mechanism Involving Caspase-8 Activation. J. Virol. 2004, 78, 6543-6555. [CrossRef] [PubMed] 
279. Morimoto, K.; Hooper, D.C.; Spitsin, S.; Koprowski, H.; Dietzschold, B. Pathogenicity of different rabies virus variants inversely correlates with apoptosis and rabies virus glycoprotein expression in infected primary neuron cultures. J. Virol. 1999, 73, 510-518. [CrossRef]

280. Kojima, I.; Izumi, F.; Ozawa, M.; Fujimoto, Y.; Okajima, M.; Ito, N.; Sugiyama, M.; Masatani, T. Analyses of cell death mechanisms related to amino acid substitution at position 95 in the rabies virus matrix protein. J. Gen. Virol. 2021, 102. [CrossRef]

281. Gholami, A.; Kassis, R.; Real, E.; Delmas, O.; Guadagnini, S.; Larrous, F.; Obach, D.; Prevost, M.-C.; Jacob, Y.; Bourhy, H. Mitochondrial dysfunction in lyssavirus-induced apoptosis. J. Virol. 2008, 82, 4774-4784. [CrossRef] [PubMed]

282. Dolman, C.L.; Charlton, K.M. Massive necrosis of the brain in rabies. Can. J. Neurol. Sci. J. Can. Sci. Neurol. 1987, 14, 162-165. [CrossRef] [PubMed]

283. Mesquita, L.P.; Gamon, T.H.M.; Cuevas, S.E.C.; Asano, K.M.; de Oliveira Fahl, W.; Iamamoto, K.; Scheffer, K.C.; Achkar, S.M.; Zanatto, D.A.; Mori, C.M.C.; et al. A rabies virus vampire bat variant shows increased neuroinvasiveness in mice when compared to a carnivore variant. Arch. Virol. 2017, 162, 3671-3679. [CrossRef]

284. Li, X.-Q.; Sarmento, L.; Fu, Z.F. Degeneration of neuronal processes after infection with pathogenic, but not attenuated, rabies viruses. J. Virol. 2005, 79, 10063-10068. [CrossRef]

285. Yan, X.; Prosniak, M.; Curti, M.T.; Weiss, M.L.; Faber, M.; Dietzschold, B.; Fu, Z.F. Silver-haired bat rabies virus variant does not induce apoptosis in the brain of experimentally infected mice. J. Neurovirol. 2001, 7, 518-527. [CrossRef]

286. Scott, C.A.; Rossiter, J.P.; Andrew, R.D.; Jackson, A.C. Structural Abnormalities in Neurons Are Sufficient to Explain the Clinical Disease and Fatal Outcome of Experimental Rabies in Yellow Fluorescent Protein-Expressing Transgenic Mice. J. Virol. 2008, 82, 513-521. [CrossRef]

287. Lindqvist, R.; Mundt, F.; Gilthorpe, J.D.; Wölfel, S.; Gekara, N.O.; Kröger, A.; Överby, A.K. Fast type I interferon response protects astrocytes from flavivirus infection and virus-induced cytopathic effects. J. Neuroinflamm. 2016, 13, 277. [CrossRef]

288. Bsibsi, M.; Persoon-Deen, C.; Verwer, R.W.H.; Meeuwsen, S.; Ravid, R.; Van Noort, J.M. Toll-like receptor 3 on adult human astrocytes triggers production of neuroprotective mediators. Glia 2006, 53, 688-695. [CrossRef]

289. Rehwinkel, J.; Gack, M.U. RIG-I-like receptors: Their regulation and roles in RNA sensing. Nat. Rev. Immunol. 2020, 20 , 537-551. [CrossRef]

290. Chauhan, V.S.; Furr, S.R.; Sterka, D.G.; Nelson, D.A.; Moerdyk-Schauwecker, M.; Marriott, I.; Grdzelishvili, V.Z. Vesicular stomatitis virus infects resident cells of the central nervous system and induces replication-dependent inflammatory responses. Virology 2010, 400, 187-196. [CrossRef]

291. Zhao, P.; Zhao, L.; Zhang, K.; Feng, H.; Wang, H.; Wang, T.; Xu, T.; Feng, N.; Wang, C.; Gao, Y.; et al. Infection with street strain rabies virus induces modulation of the microRNA profile of the mouse brain. Virol. J. 2012, 9, 159. [CrossRef]

292. Diniz, L.P.; Matias, I.; Siqueira, M.; Stipursky, J.; Gomes, F.C.A. Astrocytes and the TGF- $\beta 1$ Pathway in the Healthy and Diseased Brain: A Double-Edged Sword. Mol. Neurobiol. 2019, 56, 4653-4679. [CrossRef] [PubMed]

293. Ceyzériat, K.; Abjean, L.; Carrillo-de Sauvage, M.A.; Ben Haim, L.; Escartin, C. The complex STATes of astrocyte reactivity: How are they controlled by the JAK-STAT3 pathway? Neuroscience 2016, 330, 205-218. [CrossRef] [PubMed]

294. Nakamichi, K.; Inoue, S.; Takasaki, T.; Morimoto, K.; Kurane, I. Rabies Virus Stimulates Nitric Oxide Production and CXC Chemokine Ligand 10 Expression in Macrophages through Activation of Extracellular Signal-Regulated Kinases 1 and 2. J. Virol. 2004, 78, 9376-9388. [CrossRef]

295. Michlmayr, D.; McKimmie, C.S.; Pingen, M.; Haxton, B.; Mansfield, K.; Johnson, N.; Fooks, A.R.; Graham, G.J. Defining the Chemokine Basis for Leukocyte Recruitment during Viral Encephalitis. J. Virol. 2014, 88, 9553-9567. [CrossRef] [PubMed]

296. Besson, B.; Kim, S.; Kim, T.; Ko, Y.; Lee, S.; Larrous, F.; Song, J.; Shum, D.; Grailhe, R.; Bourhy, H. Kinome-Wide RNA Interference Screening Identifies Mitogen-Activated Protein Kinases and Phosphatidylinositol Metabolism as Key Factors for Rabies Virus Infection. mSphere 2019, 4. [CrossRef] [PubMed]

297. Kalita, J.; Srivastava, R.; Mishra, M.K.; Basu, A.; Misra, U.K. Cytokines and chemokines in viral encephalitis: A clinicoradiological correlation. Neurosci. Lett. 2010, 473, 48-51. [CrossRef]

298. Chen, C.-J.; Chen, J.-H.; Chen, S.-Y.; Liao, S.-L.; Raung, S.-L. Upregulation of RANTES Gene Expression in Neuroglia by Japanese Encephalitis Virus Infection. J. Virol. 2004, 78, 12107-12119. [CrossRef] [PubMed]

299. Bhowmick, S.; Duseja, R.; Das, S.; Appaiahgiri, M.B.; Vrati, S.; Basu, A. Induction of IP-10 (CXCL10) in astrocytes following Japanese encephalitis. Neurosci. Lett. 2007, 414, 45-50. [CrossRef]

300. McKimmie, C.; Michlmayr, D. Role of CXCL10 in central nervous system inflammation. Int. J. Interf. Cytokine Mediat. Res. 2014, 6, 1. [CrossRef]

301. Ma, Y.; He, B. Recognition of herpes simplex viruses: Toll-like receptors and beyond. J. Mol. Biol. 2014, 426, 1133-1147. [CrossRef]

302. Mogensen, T.H. Pathogen recognition and inflammatory signaling in innate immune defenses. Clin. Microbiol. Rev. 2009, 22, 240-273. [CrossRef]

303. Perry, A.K.; Chen, G.; Zheng, D.; Tang, H.; Cheng, G. The host type I interferon response to viral and bacterial infections. Cell Res. 2005, 15, 407-422. [CrossRef] [PubMed]

304. Nan, Y.; Wu, C.; Zhang, Y.-J. Interplay between Janus Kinase/Signal Transducer and Activator of Transcription Signaling Activated by Type I Interferons and Viral Antagonism. Front. Immunol. 2017, 8, 1758. [CrossRef] [PubMed]

305. Chiu, Y.-H.; Macmillan, J.B.; Chen, Z.J. RNA polymerase III detects cytosolic DNA and induces type I interferons through the RIG-I pathway. Cell 2009, 138, 576-591. [CrossRef] 
306. Piret, J.; Boivin, G. Innate immune response during herpes simplex virus encephalitis and development of immunomodulatory strategies. Rev. Med. Virol. 2015, 25, 300-319. [CrossRef]

307. Wang, Y.; Jia, J.; Wang, Y.; Li, F.; Song, X.; Qin, S.; Wang, Z.; Kitazato, K.; Wang, Y. Roles of HSV-1 infection-induced microglial immune responses in CNS diseases: Friends or foes? Crit. Rev. Microbiol. 2019, 45, 581-594. [CrossRef]

308. Kurt-Jones, E.A.; Chan, M.; Zhou, S.; Wang, J.; Reed, G.; Bronson, R.; Arnold, M.M.; Knipe, D.M.; Finberg, R.W. Herpes simplex virus 1 interaction with Toll-like receptor 2 contributes to lethal encephalitis. Proc. Natl. Acad. Sci. USA 2004, 101, 1315-1320. [CrossRef]

309. Wang, J.P.; Bowen, G.N.; Zhou, S.; Cerny, A.; Zacharia, A.; Knipe, D.M.; Finberg, R.W.; Kurt-Jones, E.A. Role of specific innate immune responses in herpes simplex virus infection of the central nervous system. J. Virol. 2012, 86, 2273-2281. [CrossRef]

310. Kato, H.; Takeuchi, O.; Sato, S.; Yoneyama, M.; Yamamoto, M.; Matsui, K.; Uematsu, S.; Jung, A.; Kawai, T.; Ishii, K.J.; et al. Differential roles of MDA5 and RIG-I helicases in the recognition of RNA viruses. Nature 2006, 441, 101-105. [CrossRef] [PubMed]

311. Sorensen, L.N.; Reinert, L.S.; Malmgaard, L.; Bartholdy, C.; Thomsen, A.R.; Paludan, S.R. TLR2 and TLR9 synergistically control herpes simplex virus infection in the brain. J. Immunol. 2008, 181, 8604-8612. [CrossRef] [PubMed]

312. Menasria, R.; Boivin, N.; Lebel, M.; Piret, J.; Gosselin, J.; Boivin, G. Both TRIF and IPS-1 Adaptor Proteins Contribute to the Cerebral Innate Immune Response against Herpes Simplex Virus 1 Infection. J. Virol. 2013, 87, 7301-7308. [CrossRef] [PubMed]

313. Pham, T.H.; Kwon, K.M.; Kim, Y.-E.; Kim, K.K.; Ahn, J.-H. DNA sensing-independent inhibition of herpes simplex virus 1 replication by DAI/ZBP1. J. Virol. 2013, 87, 3076-3086. [CrossRef] [PubMed]

314. Liu, Y.; Goulet, M.-L.; Sze, A.; Hadj, S.B.; Belgnaoui, S.M.; Lababidi, R.R.; Zheng, C.; Fritz, J.H.; Olagnier, D.; Lin, R. RIG-I-Mediated STING Upregulation Restricts Herpes Simplex Virus 1 Infection. J. Virol. 2016, 90, 9406-9419. [CrossRef] [PubMed]

315. Lafaille, F.G.; Pessach, I.M.; Zhang, S.Y.; Ciancanelli, M.J.; Herman, M.; Abhyankar, A.; Ying, S.W.; Keros, S.; Goldstein, P.A.; Mostoslavsky, G.; et al. Impaired intrinsic immunity to HSV-1 in human iPSC-derived TLR3-deficient CNS cells. Nature 2012, 491, 769-773. [CrossRef]

316. Rosato, P.C.; Leib, D.A. Neuronal Interferon Signaling Is Required for Protection against Herpes Simplex Virus Replication and Pathogenesis. PLoS Pathog. 2015, 11. [CrossRef]

317. Cho, H.; Proll, S.C.; Szretter, K.J.; Katze, M.G.; Gale, M.; Diamond, M.S. Differential innate immune response programs in neuronal subtypes determine susceptibility to infection in the brain by positive-stranded RNA viruses. Nat. Med. 2013, 19, 458-464. [CrossRef]

318. Farmer, J.R.; Altschaefl, K.M.; O'Shea, K.S.; Miller, D.J. Activation of the Type I Interferon Pathway Is Enhanced in Response to Human Neuronal Differentiation. PLoS ONE 2013, 8, e58813. [CrossRef] [PubMed]

319. Schultz, K.L.W.; Vernon, P.S.; Griffin, D.E. Differentiation of Neurons Restricts Arbovirus Replication and Increases Expression of the Alpha Isoform of IRF-7. J. Virol. 2015, 89, 48-60. [CrossRef]

320. Lokensgard, J.R.; Cheeran, M.C.; Hu, S.; Gekker, G.; Peterson, P.K. Glial cell responses to herpesvirus infections: Role in defense and immunopathogenesis. J. Infect. Dis. 2002, 186 (Suppl. S2), S171-S179. [CrossRef]

321. Cédile, O.; Wlodarczyk, A.; Owens, T. CCL2 recruits T cells into the brain in a CCR2-independent manner. Apmis 2017, 125, 945-956. [CrossRef]

322. Robichon, K.; Patel, V.; Connor, B.; La Flamme, A.C. Clozapine reduces infiltration into the CNS by targeting migration in experimental autoimmune encephalomyelitis. J. Neuroinflamm. 2020, 17, 53. [CrossRef]

323. Ransohoff, R.M.; Hamilton, T.A.; Tani, M.; Stoler, M.H.; Shick, H.E.; Major, J.A.; Estes, M.L.; Thomas, D.M.; Tuohy, V.K. Astrocyte expression of mRNA encoding cytokines IP-10 and JE/MCP-1 in experimental autoimmune encephalomyelitis. FASEB J. Off. Publ. Fed. Am. Soc. Exp. Biol. 1993, 7, 592-600. [CrossRef] [PubMed]

324. Broad, A.; Kirby, J.A.; Jones, D.E.; Applied, I.; Transplantation Research, G. Toll-like receptor interactions: Tolerance of MyD88dependent cytokines but enhancement of MyD88-independent interferon-beta production. Immunology 2007, 120, 103-111. [CrossRef] [PubMed]

325. Chucair-Elliott, A.J.; Conrady, C.; Zheng, M.; Kroll, C.M.; Lane, T.E.; Carr, D.J. Microglia-induced IL-6 protects against neuronal loss following HSV-1 infection of neural progenitor cells. Glia 2014, 62, 1418-1434. [CrossRef]

326. Marques, C.P.; Hu, S.; Sheng, W.; Lokensgard, J.R. Microglial cells initiate vigorous yet non-protective immune responses during HSV-1 brain infection. Virus Res. 2006, 121, 1-10. [CrossRef] 